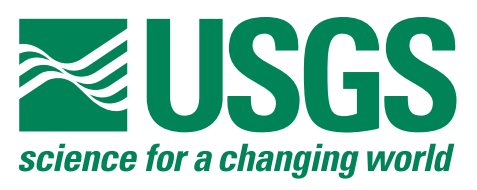

\title{
Rainfall Thresholds for Forecasting Landslides in the Seattle, Washington, Area-Exceedance and Probability
}

By Alan F. Chleborad, Rex L. Baum, and Jonathan W. Godt

U.S. Geological Survey Open-File Report 2006-1064 


\section{U.S. Department of the Interior \\ P. Lynn Scarlett, Acting Secretary}

\section{U.S. Geological Survey \\ P. Patrick Leahy, Acting Director}

U.S. Geological Survey, Reston, Virginia 2006

For product and ordering information:

World Wide Web: http://www.usgs.gov/pubprod

Telephone: 1-888-ASK-USGS

For more information on the USGS - the Federal source for science about the Earth, its natural and living resources, natural hazards, and the environment:

World Wide Web: http://www.usgs.gov

Telephone: 1-888-ASK-USGS

Chleborad, A.F., Baum, R.L., and Godt, J.W., 2006, Rainfall thresholds for forecasting landslides in the Seattle, Washington, area-Exceedance and probability: U.S. Geological Survey Open-File Report 2006-1064.

Any use of trade, firm, or product names is for descriptive purposes only and does not imply endorsement by the U.S. Government.

Although this report is in the public domain, permission must be secured from the individual copyright owners to reproduce any copyrighted material contained within this report. 


\section{Contents}

Abstract tow

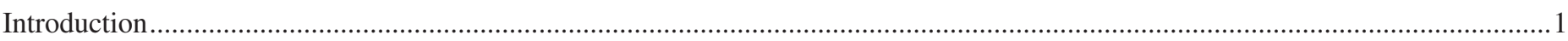

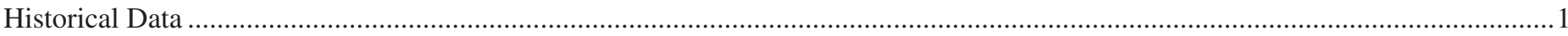

Landslide Database

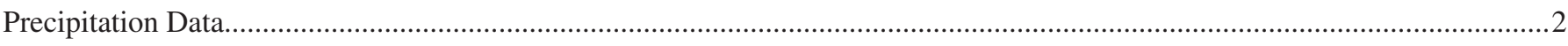

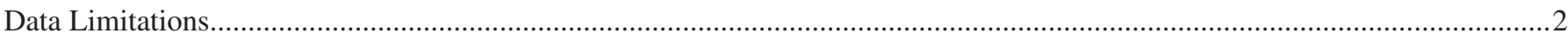

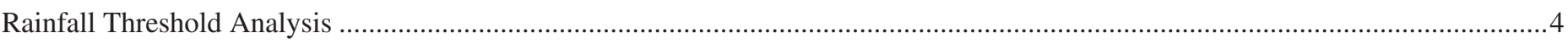

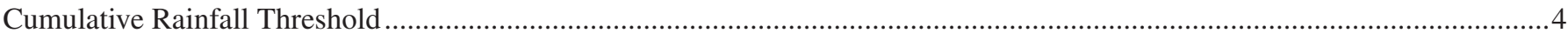

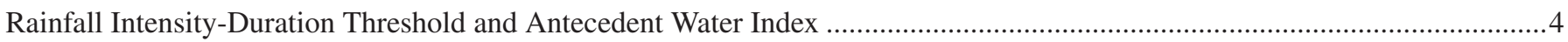

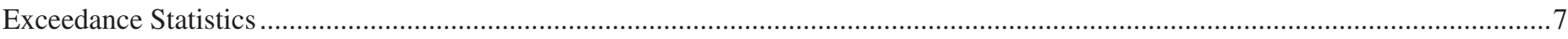

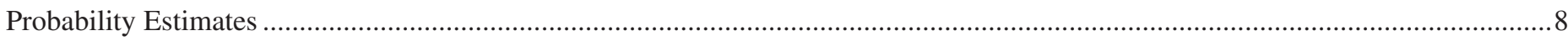

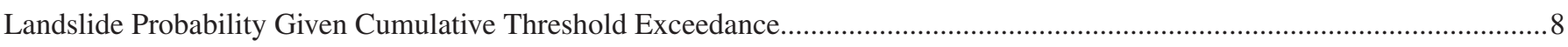

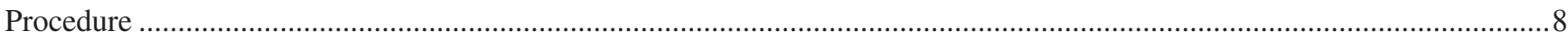

Probability Estimates for Cumulative Threshold Exceedance.................................................................................... 14

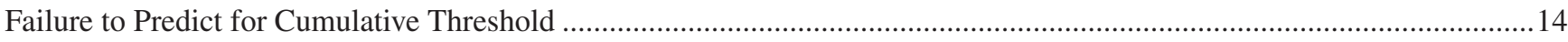

Landslide Probability for Intensity-Duration Threshold and Antecedent Water Index Exceedance ..........................................14

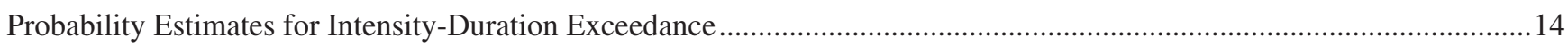

Failure to Predict for Intensity-Duration Threshold and Antecedent Water Index ...........................................................15

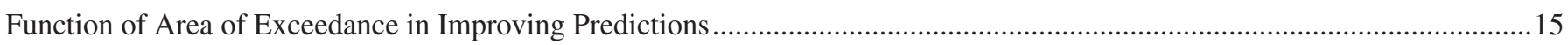

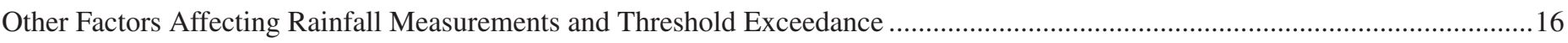

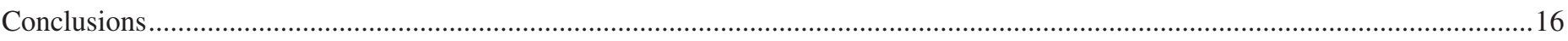

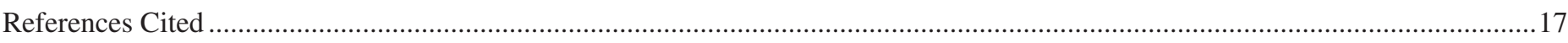

\section{Figures}

Figure 1. Map showing locations of City of Seattle rain gages and 432 landslides in the database used to evaluate the thresholds.....3

Figure 2. Cumulative 3-Day and Previous 15-day Rainfall Threshold (A) Preliminary graph showing estimates of 3-day and prior 15-day cumulative precipitation associated with historical landslides that were part of events with three or more landslides in a 3-day period, in Seattle (B) Graph showing antecedent precipitation associated with an expanded database of 199 historical

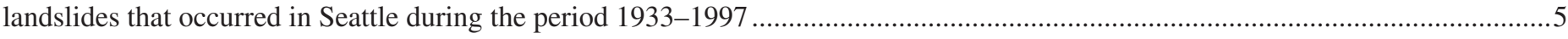

Figure 3. Rainfall Intensity and Duration Threshold (ID) for Seattle, Washington.....................................................................

\section{Tables}

Table 1. 1978-2003 database of 577 Seattle landslides with known dates of occurrence ...........................................................18

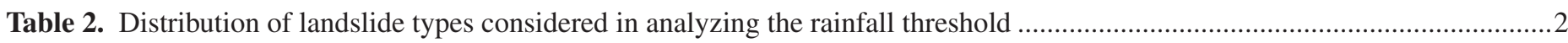

Table 3. Cumulative 3-day and previous 15-day rainfall threshold (CT) exceedance at rain gages in the Seattle Rain Gage Network, 1978-2003.

Table 4. Exceedance statistics for cumulative 3-day and previous 15-day threshold (CT) at the three nearest rain gages to each

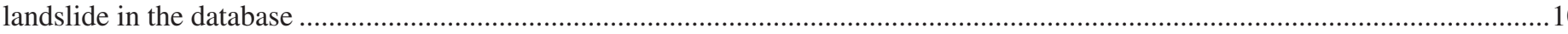

Table 5. Rain-gage agreement with regard to exceedance or nonexceedance of cumulative 3-day and previous 15-day threshold (CT)

Table 6. Lumped exceedance statistics for cumulative 3-day and previous 15-day threshold (CT) at the three nearest rain gages to each landslide in the database......

Table 7. Probability of landslide occurrence in Seattle relative to the 3-day and previous 15-day cumulative rainfall threshold (CT) based on number of unique days the threshold was exceeded at any rain gage from 1978-2003..... 
Table 8. Minimum probability of landslide occurrence in Seattle relative to the rainfall intensity-duration threshold (ID) and ID combined with the antecedent water index (AWI) based on number of days the threshold was exceeded at any rain gage from 1978-2003

Table 9. Probability of landslide occurrence in Seattle relative to the rainfall intensity-duration threshold (ID) based on number of days the threshold was exceeded at 3 or more and 10 or more rain gages from 1978 to 2003

\section{Conversion Factors}

Inch/Pound to SI

\begin{tabular}{|c|c|c|}
\hline Multiply & By & To obtain \\
\hline \multicolumn{3}{|c|}{ Length } \\
\hline inch & 25.4 & millimeter $(\mathrm{mm})$ \\
\hline foot (ft.) & 0.3048 & meter $(\mathrm{m})$ \\
\hline mile (mi) & 1.609 & kilometer $(\mathrm{km})$ \\
\hline \multicolumn{3}{|l|}{ SI to Inch/Pound } \\
\hline Multiply & By & To obtain \\
\hline \multicolumn{3}{|c|}{ Length } \\
\hline millimeter $(\mathrm{mm})$ & 0.03937 & inch \\
\hline meter $(\mathrm{m})$ & 3.281 & foot (ft) \\
\hline kilometer $(\mathrm{km})$ & 0.6214 & mile (mi) \\
\hline
\end{tabular}




\title{
Rainfall Thresholds for Forecasting Landslides in the Seattle, Washington, Area-Exceedance and Probability
}

\author{
By Alan F. Chleborad, Rex L. Baum, and Jonathan W. Godt
}

\section{Abstract}

Empirical rainfall thresholds and related information form a basis for forecasting landslides in the Seattle area. A formula for a cumulative rainfall threshold (CT), $P_{3}=3.5-0.67 P_{15}$, defined by rainfall amounts (in inches) during the last 3 days (72 hours), $P_{3}$, and the previous 15 days (360 hours), $P_{15}$, was developed from analysis of historical data for 91 landslides that occurred as part of 3-day events of three or more landslides between 1933 and 1997. Comparison with historical records for 577 landslides (including some used in developing the CT) indicates that the CT captures more than 90 percent of historical landslide events of three or more landslides in 1-day and 3-day periods that were recorded from 1978 to 2003 . However, the probability of landslide occurrence on a day when the $\mathrm{CT}$ is exceeded at any single rain gage ( 8.4 percent) is low, and additional criteria are needed to confidently forecast landslide occurrence. Exceedance of a rainfall intensity-duration threshold $I=3.257 D^{-1.13}$, for

intensity, $I$, (inch per hour) and duration, $D$, (hours), corresponds to a higher probability of landslide occurrence (42 percent at any 3 rain gages or 65 percent at any 10 rain gages), but it predicts fewer landslides. Both thresholds must be used in tandem to forecast landslide occurrence in Seattle.

\section{Introduction}

Landslides occurring on bluffs and hillsides of Seattle, Washington, and other communities in the Puget Sound region pose a significant hazard to people, public and private property, utilities, and businesses. Landslides occur almost every year during the wet season, which usually lasts from October through April (Thorsen, 1989). Winter storms have initiated many landslides in 1934, 1972, 1986, 1990, 1996, 1997, and 2001 (Tubbs, 1974; Laprade, 1986; Miller, 1991; Gerstel, 1996; E.L. Harp, USGS, unpub. data, 1996; Gerstel and others, 1997; Baum and others, 1998; Laprade and others, 2000; Chleborad, 2003). Landslides in 1996 and 1997 caused major damage to private and public property and the deaths of four persons on Bainbridge Island (E.L. Harp, USGS, unpub. data, 1996; M. Pageler, Seattle City Council, unpub. data, 1998; Baum and others, 1998). The strong association between major landslide events and rainfall as well as increasing needs to anticipate landslide activity to protect public safety and reduce landslide-related losses in Seattle motivated the U.S. Geological Survey (USGS) rainfall threshold research for the Seattle area. Consequently, in 1999, the USGS began a project to identify precipitation thresholds that might be used to anticipate or forecast the occurrence of landslides. The study focused on the compilation and analysis of historical, wet-season landslide and climatic data to explore the observed relationship between rainfall and landslides. The effort resulted in the identification of an empirically derived 3-day and prior 15-day cumulative precipitation threshold for the occurrence of landslides in Seattle (Chleborad, 2000). Godt (2004) also developed an empirically derived rainfall intensity-duration threshold.

Results of a comprehensive study of historical landslides in Seattle (using data that date back to 1897; Laprade and others, 2000) show that a high percentage of reported landslides occurred in the November through April timeframe. Precipitation in the form of rain, and occasionally snow, is a major factor in the occurrence of landslides. Cyclonic storms that develop over the Pacific Ocean and move inland account for much of the wet-season precipitation. Average November through April precipitation in the Seattle area is approximately 28.0 inches $(711 \mathrm{~mm})$, or 73 percent of the mean annual precipitation of 38.2 inches $(970 \mathrm{~mm})$; thus almost three-fourths of the rain falls in one-half of the year, implying a rainfall rate in the NovemberApril rainy season that is almost 3 times the rate in the drier season.

In this report, we briefly review the landslide thresholds (Chleborad, 2000, 2003; Godt 2004; Godt and others, 2006), summarize a database of historical landslides used to test the thresholds, summarize our statistical analyses of the rainfall thresholds' exceedance, and describe estimates of the probability of landslide occurrence given exceedance.

\section{Historical Data}

\section{Landslide Database}

The landslide database compiled for this analysis consists of information on 577 reported landslides that occurred in the city of Seattle during the period 1978-2003 (table 1, fig. 1). Information on location, date of occurrence, and landslide type are included in the compilation. The primary data source is the Shannon and Wilson database of historical landslides compiled for the City of Seattle as part of a comprehensive report on Seattle landslides 
(Laprade and others, 2000). Other sources include the City of Seattle landslide files, U.S. Geological Survey reports (E.L Harp, unpub. data, 1996; Baum and others, 1998; Chleborad, 2000, 2003), updates to the Shannon and Wilson landslide database, and newspaper reports. The following reported landslides were excluded from our compilation: (1) Landslides identified as not natural, such as landslides initiated by excavation, landslides with a "false" in the date confidence field of the Shannon and Wilson database, and landslides with addresses that could not be located on street maps of Seattle; (2) reported landslides with unknown dates of occurrence (date considered unknown if it could not be confirmed to within a few days); (3) duplicate landslides (those already included in the database); (4) landslides that were likely initiated by the Nisqually Earthquake of February 28, 2001.

In this report, the term landslide includes various types of slope failures both on engineered and on natural slopes. Typically, the landslides exhibited one or more of the following types of movement involving earth or debris: translational slides, flows, rotational slumps, and topples or falls (see Cruden and Varnes, 1996). It should be noted that studies of landslide occurrence in the Seattle area often reveal a contributing human influence (such as placement of fill materials, improper drainage, leaking or broken water pipes, blocked culverts, excavation, and so forth). In their comprehensive study of historical landslides, Laprade and others (2000) state that a human influence was reported for 84 percent of the landslides in their database of approximately 1,400 historical landslides. The contribution of the human influence factors relative to other factors, however, was not determined. At the generalized scale of this study we treated human influence as a uniform condition because few, if any, undisturbed areas remain in Seattle, and human influence was reported in a majority of the landslides in our database of 577 landslides with known dates of occurrence.

The majority of the 577 landslides in our database are shallow earth or debris slides (usually in colluvium, with a depth less than $2 \mathrm{~m}$ ), with the remainder being deep earth slides, sand or debris flows, and earth or debris falls. These landslides correspond to four types used in the Shannon and Wilson database (Laprade and others, 2000) as indicated in table 2. The nonstandard terms adopted by Laprade and others (2000) deserve further explanation. A ground-water blowout is a slope failure that occurs where a relatively impermeable deposit is overlain by a permeable deposit; high pore-water pressures that develop in perched water at the base of the permeable deposit result in a sand or debris "blowout" (flow). A high-bluff peel-off is a fall, slide, or topple that occurs on a near-vertical cliff face in glacial or other granular sediment. As indicated in table 2, at least 86 percent (76 percent +10 percent) of the landslides in our database are earth or debris slides, and most (76 percent) are shallow.

Precipitation was the major natural cause of landslides in the database of approximately 1400 historical landslides compiled by Laprade and others (2000) and discussed by Coe and others (2004). Ninety-six percent of the 577 landslides in the database compiled for this report occurred during annual November-April wet seasons. As noted previously, however, human influence may have been a factor in the occurrence or initiation of many of the landslides.

\section{Precipitation Data}

Ideally, measurements of precipitation would be made with recording devices located at the landslide sites. Because such measurements are rare or do not exist, data from City of Seattle rain-gage network (fig. 1), located closest to the respective landslide locations, were used for our analysis of threshold exceedance and to estimate probability of landslide occurrence. In nearly all cases, the selected stations are located within a few miles of the respective landslides, and it is assumed that the data are sufficiently representative of conditions at the respective landslide locations (M.G. Schaefer, MGS Engineering Consultants Inc., unpub. data, 2003). Hourly data from the Seattle network were available for the period from 1978 through 2003 at the time the analysis was performed. A few of the gages in the network have incomplete records due to gage malfunction, construction at the gage site, or other unknown circumstances.

\section{Data Limitations}

The quality of information on landslides and associated precipitation compiled for this report is variable. Original source documents and reports were carefully examined in an effort to obtain the most accurate data on landslide timing and locations. Nearly all of the landslide locations were field checked, and photographs of the sites were taken. However, the landslides were not studied in detail, and only minimal descriptive information

Table 2. Distribution of landslide types considered in analyzing the rainfall threshold. [m, meters; <, less than; >, greater than]

\begin{tabular}{llc}
\hline \multicolumn{1}{c}{ Varnes (1978) classification } & \multicolumn{1}{c}{$\begin{array}{c}\text { Laprade and others (2000) } \\
\text { terminology }\end{array}$} & $\begin{array}{c}\text { Percentage of entries in 577- } \\
\text { member landslide database }\end{array}$ \\
\hline Earth or debris slide & Shallow landslide $(<2 \mathrm{~m} \mathrm{deep)}$ & 76 \\
Earth or debris slide & Deep landslide $(>2 \mathrm{~m}$ deep $)$ & 10 \\
Sand or debris flow & Ground-water blowout & 3 \\
Earth or debris fall & High-bluff peel-off & 4 \\
Undetermined & Undetermined & 7 \\
\hline
\end{tabular}




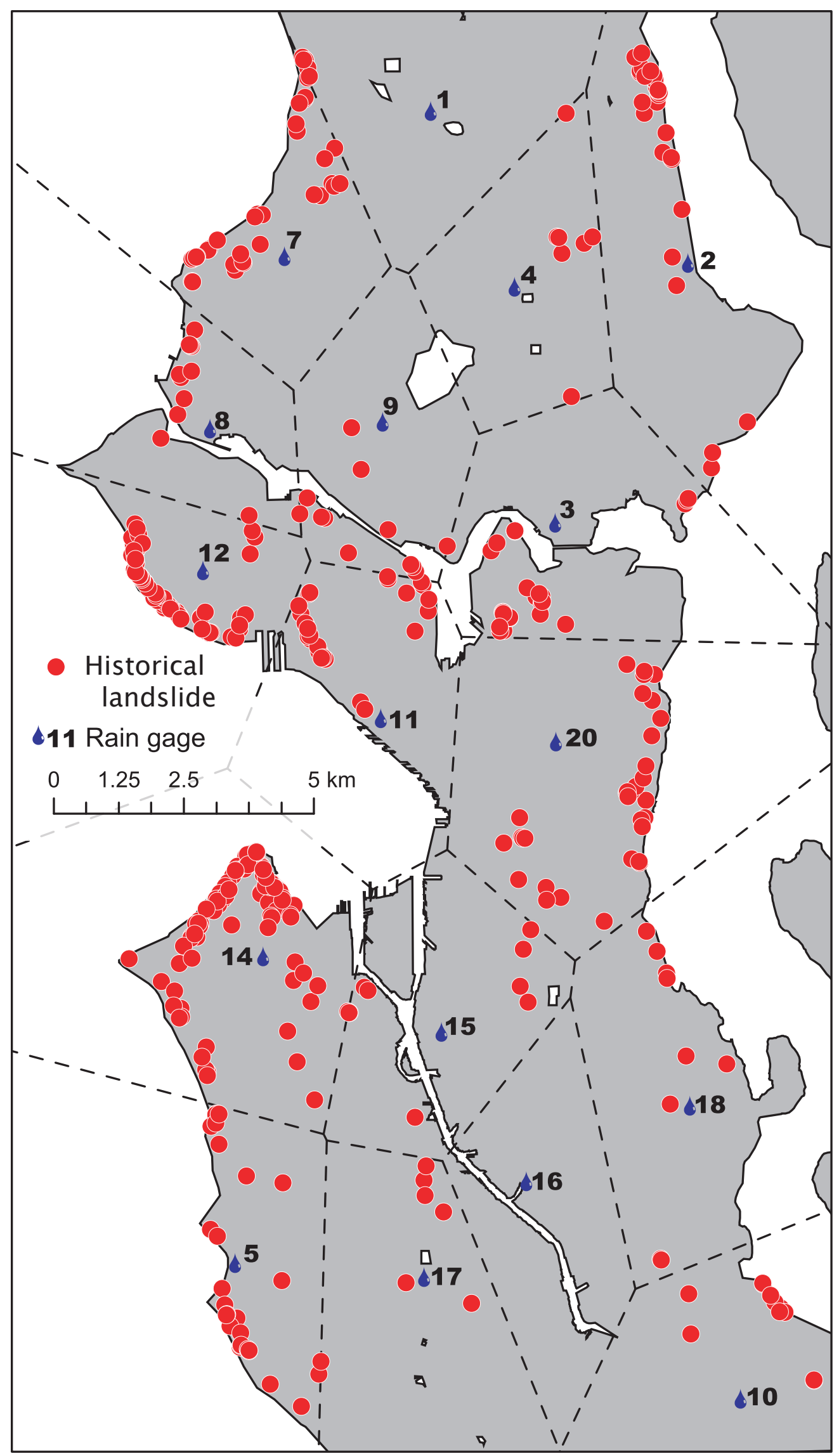

Figure 1. Map showing locations of City of Seattle rain gages and 432 landslides in the database used to evaluate the thresholds. Landslides shown have coordinate locations in the City of Seattle landslide database (Laprade and others, 2000); the remaining 145 landslides have only address locations (table 1). Dashed lines bound polygons centered on each rain gage that define their domains. 
was obtained. The search yielded few eyewitness accounts. Times of occurrence are inferred on the basis of available information from various sources. Sources include the City of Seattle database of landslides (unpub. data, 2001-2003), City of Seattle landslide specialists, geotechnical consultants, newspaper reports, and local residents.

Several limitations affect the accuracy and completeness of historical landslide data compiled for Seattle (Laprade and others, 2000; Chleborad, 2000, 2003; Coe and others, 2004). Nonreporting of landslides and uncertainties in the time of occurrence are the limitations that bear most directly on the analysis and conclusions presented in this report.

Reporting of landslides: Reported landslides are most often those that occurred in developed areas that damaged, or threatened to damage, roadways, residential or commercial property, utilities or high-use public property. The degree of nonreporting during the period 1978-2003 is unknown; however, an examination of the record of reported landslides in previously undeveloped areas of Seattle that are susceptible to landslide occurrence suggests that a significant number of landslides may go unreported (Coe and others, 2004). Therefore, it may be that a considerable number of landslides occurred in Seattle during the period 1978-2003 that are not included in the database (table 1). Consequently, total numbers of landslides over given intervals of time and percentages and probabilities based on those totals are considered to be the minimum.

Times of occurrence: In conjunction with accurate precipitation records, accurate times of landslide occurrence are needed to estimate amounts of antecedent precipitation associated with landslide occurrence. Exact times (to the nearest hour) of occurrence are usually unknown or unreported, and the accuracy of reported times or dates is variable. The dates of occurrence given in table 1 are from the sources previously cited and are considered the most reliable information available. However, the number, magnitude and significance of inaccuracies are unknown.

\section{Rainfall Threshold Analysis}

\section{Cumulative Rainfall Threshold}

Chleborad's (2000) cumulative precipitation threshold compares the amount of rainfall in the last 3 days ( 72 hours) to the rainfall in the previous 15 days. The cumulative 3-day/15-day precipitation threshold (CT) is based on an analysis of historical precipitation data associated with wet-season landslides in Seattle during the period 1933-1997. For brevity and consistency throughout the remainder of the paper, this threshold is referred to as the CT.

In the initial part of the study, hourly rainfall data recorded at 17 City of Seattle rain-gage sites and daily climatic data (rainfall, snowfall, and air temperature) from 12 National Weather Service sites in the Seattle area were compiled and analyzed. Antecedent precipitation amounts were estimated using data from stations closest to the individual landslide locations. Information on location and time of occurrence was obtained in a search of City of Seattle landslide files, newspaper reports, geotechnical reports, USGS landslide project files, and personal field notes. The search yielded location and time of occurrence information on 187 historical landslides (Chleborad, 2000). Most of the landslides in the database of 187 landslides are shallow slumps, slides, or debris flows (estimated failure depths less than or equal to $2 \mathrm{~m}$ ); however, the database also includes deeper landslides.

To make a prediction of landslides induced by rainfall, a level of landslide activity is needed for which it is a reasonable assumption that rainfall is causally involved. The level selected was three or more landslides in a 3-day (72-hour) period. Inspection of the database revealed that 91 of the 187 slides could be shown to be part of landslide events with three or more landslides in a 3-day period.

Given this level of landslide activity, a rainfall threshold is needed for predicting the occurrence of three or more landslides in a 3-day period. To incorporate the two ideas of antecedent wetness and unusual recent rainfall, two variables were defined: $P_{3}$ the 3-day precipitation immediately prior to the landslide event and $P_{15}$, the antecedent precipitation that occurred prior to the 3 days of $P_{3}$. A scatter plot was made of the $P_{3}$ and $P_{15}$ values corresponding to each landslide event (fig. 2A). From this scatter plot, an approximate lower-bound precipitation threshold was defined by the equation $P_{3}=3.50-0.67 P_{15}$. The precipitation threshold thus defined is interpreted as an approximate lowerbound threshold below which the specified level of precipitationinduced landslide activity does not occur, or occurs only rarely, and above which it may occur under certain conditions.

Additional data on 108 historical landslides that occurred in Seattle between 1950 and 1990 (Tubbs, 1974; Laprade and others, 2000), which were found to be part of 3-day events with three or more landslides but were not part of the original 91 landslides used to define the CT, were subsequently compiled and analyzed (Chleborad, 2003). As shown in figure 2B, the additional data are consistent with the previously defined threshold; approximately 90 percent of the added data points (filled circles) fall on or above the CT. In addition, the newly plotted data better define the CT for conditions of 15-day cumulative precipitation greater than 3.0 inches.

\section{Rainfall Intensity-Duration Threshold and Antecedent Water Index}

Godt's (2004) intensity-duration threshold (ID) and antecedent water index (AWI) were developed for forecasting major landslide events (multiple landslides in a 24-hour period) in the Seattle area. Godt and others (2006) provide a detailed description of the ID; we provide a brief description here. The ID is defined as $I=82.73 D^{-1.13}$, in which $I$ is the average rainfall intensity, in millimeters per hour, for the entire storm, and $D$ is the duration, in hours (fig. 3). For rainfall in inches, the ID is defined as $I=3.257 D^{-1.13}$. On the basis of observed hourly rainfall, rainstorms were bounded by periods of no rainfall at least 3 hours in duration at individual rain gages. 


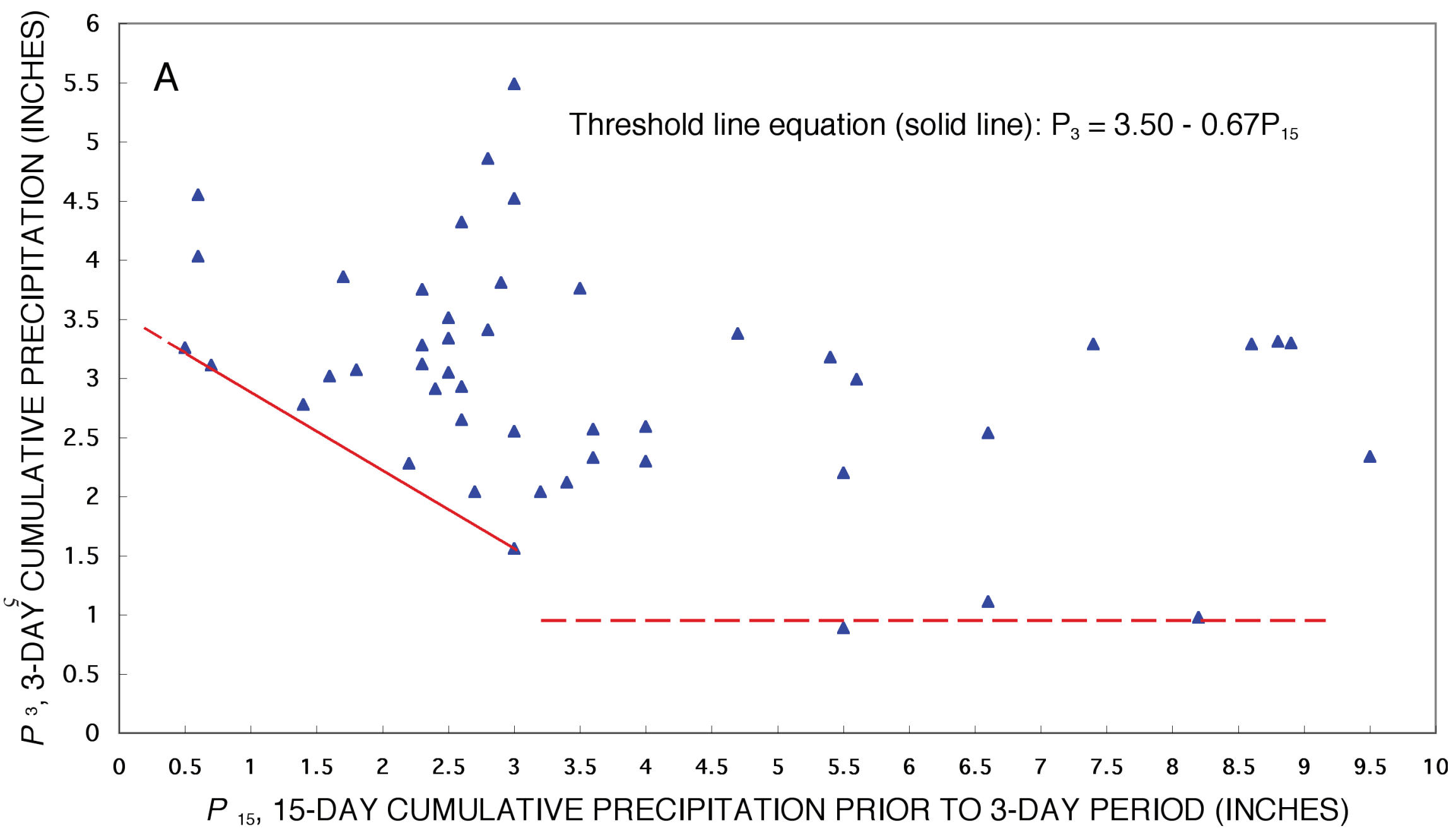

Figure 2. Cumulative 3-day and previous 15-day rainfall threshold (CT) (Chleborad, 2000, 2003) (A) Preliminary graph showing estimates of 3-day and prior 15-day cumulative precipitation associated with historical landslides that were part of events with three or more landslides in a 3-day period, in Seattle (filled triangles). The solid red line is a lower-bound threshold (visually identified) for the initiation of landslides when the 15-day cumulative is 3.0 inches or less. The dashed horizontal line is a lower-bound threshold that was tentatively proposed for conditions of 15-day antecedent precipitation exceeding 3 inches (Chleborad, 2000). (B) Graph showing antecedent precipitation associated with an expanded database of 199 historical landslides that occurred in Seattle during the period 1933-1997 (after Chleborad 2003). Based on the additional data (filled circles), the original threshold, defined by the equation $\mathrm{P}_{3}=3.5-0.67 \mathrm{P}_{15}$, was extrapolated to the $\mathrm{P}_{15}$-axis. 


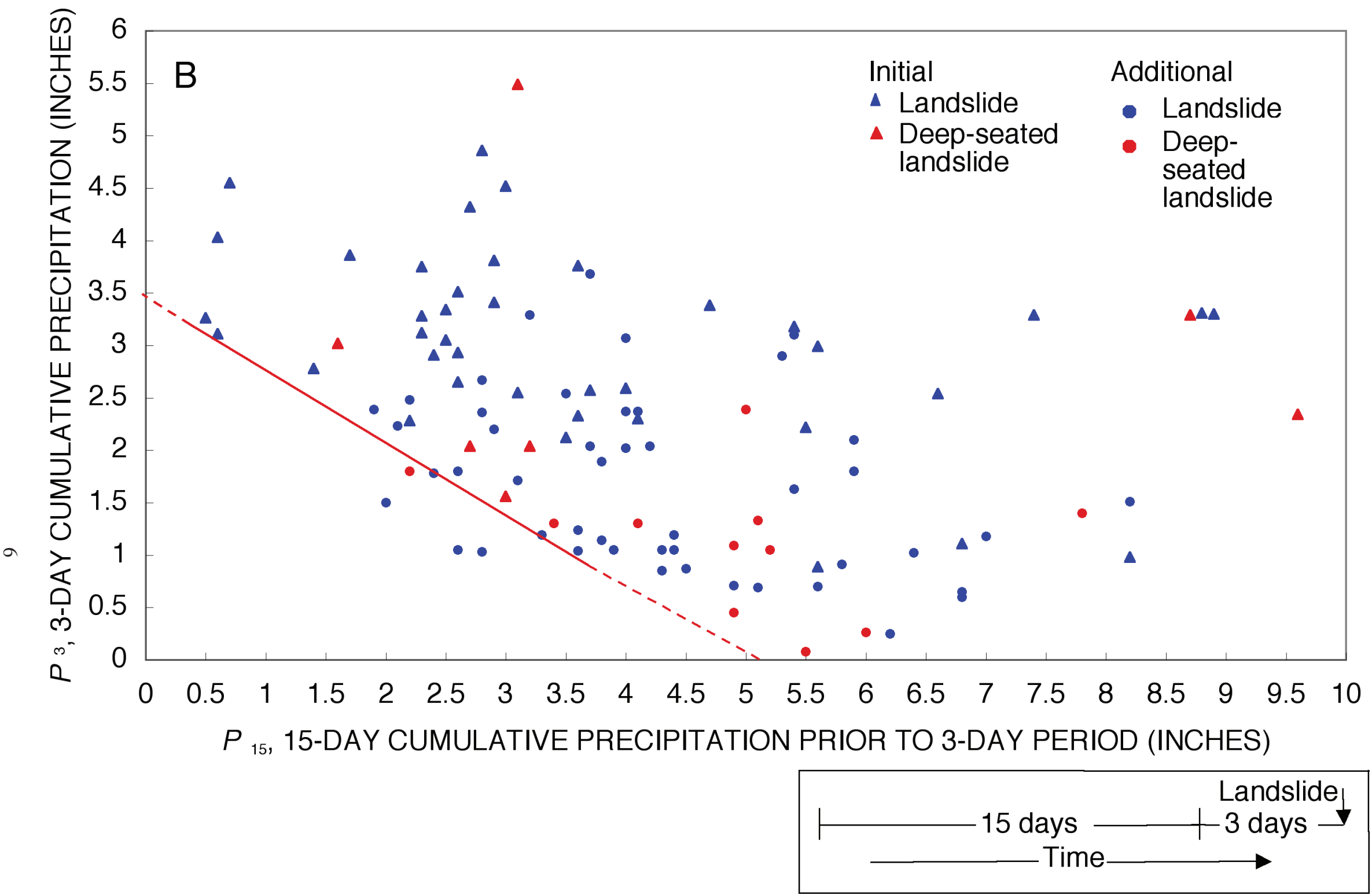




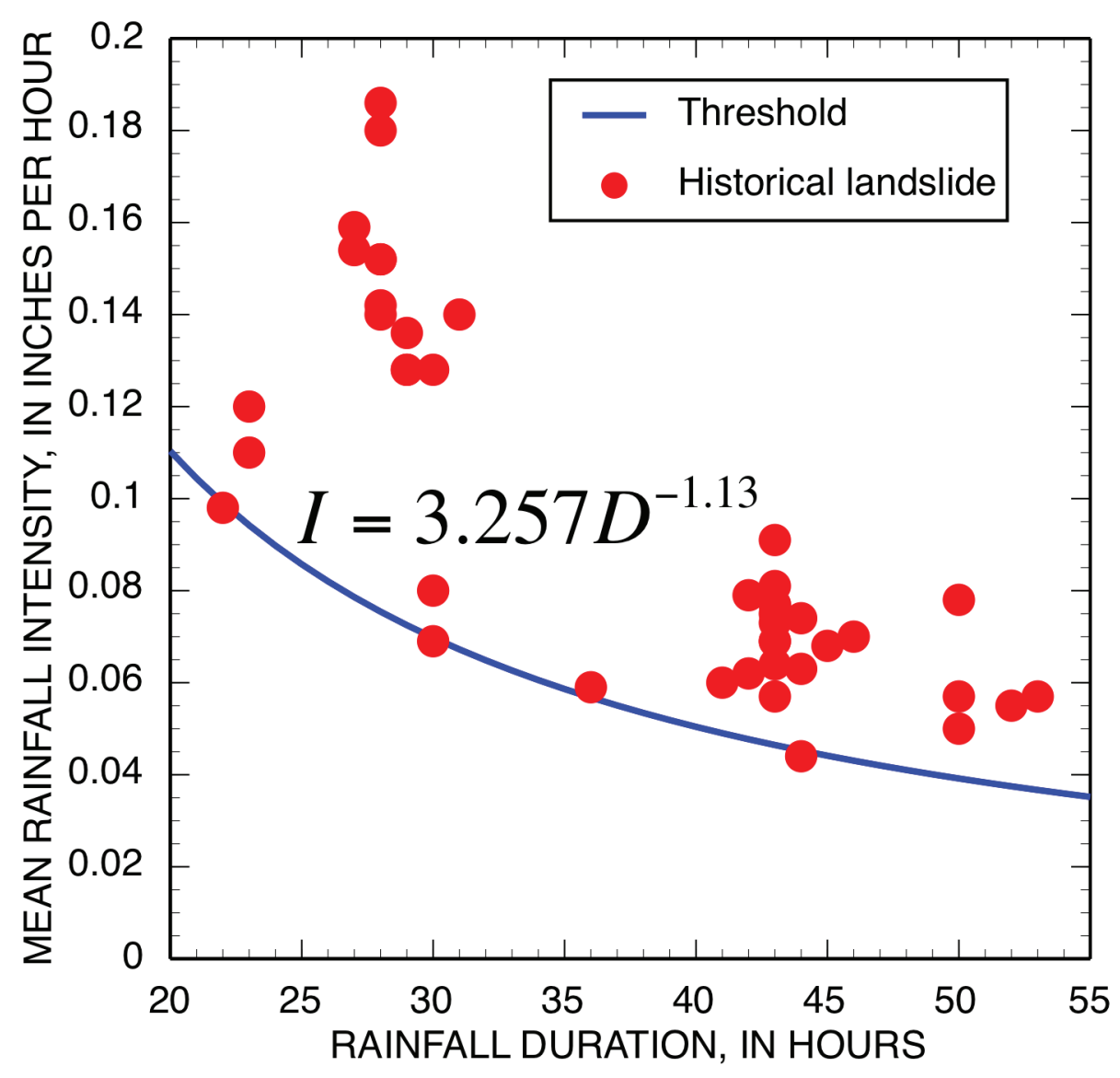

Figure 3. Rainfall intensity and duration threshold (ID) for Seattle, Washington (after Godt, 2004).
In addition to rainfall intensity and duration, prestorm (antecedent) soil wetness is a significant factor in rainfall inducement of landslides (Tubbs, 1974; Chleborad, 2000; Baum and others, 2005). The observation that landslides occur primarily during the rainy season at times when the soil is relatively wet indicates that an antecedent soil moisture threshold must be exceeded before the ID can be used. Godt (2004) and Godt and others (2006) developed the AWI as an approximate measure of antecedent soil moisture.

$$
A W I_{t}=A W I_{t-1}+\frac{I_{i}}{k_{d}}, A W I<0
$$

$$
A W I_{t}=A W I_{t-1} \exp \left(-k_{d} \Delta t\right)+\frac{I_{i}}{k_{d}}\left[1-\exp \left(-k_{d} \Delta t\right)\right], A W I \geq 0
$$

In equations $1 \mathrm{a}$ and $1 \mathrm{~b}, k_{d}$ is an empirical drainage constant ( 0.01 for rainfall in millimeters or 0.254 for rainfall in inches), $t$ is the time increment, $I_{i}$ is the current rainfall intensity minus the evapotranspiration rate, and the subscripts $t$ and $t-1$ refer to the present and previous time steps. The AWI was defined in such a way as to mimic instrumentally observed variations in soil wetness (Baum and others, 2005). However, the AWI does not account for the time lag that results from downward movement of rainwater through the soil and thus usually leads the actual soilmoisture response by several hours.

\section{Exceedance Statistics}

An ideal rainfall threshold would always discriminate between conditions that produce landslides and those that do not. In reality, precipitation-induced landslides in Seattle have sometimes occurred when conditions were below the thresholds, and conditions above the thresholds have not always produced landslides (or else the landslides were not recorded). Consequently, statistical analysis of historical records with respect to the thresholds indicates the degree of certainty or uncertainty in forecasts based on the thresholds.

In an effort to characterize the strengths and limitations of the CT, we analyzed hourly rainfall data from the Seattle raingage network to determine how many times the CT has been exceeded during the period when hourly data were available for the network (1978-2003). We also compared landslide activity (as indicated by our database of 577 landslides that occurred in Seattle from 1978 to 2003) to threshold exceedance to characterize the predictive skill of the CT. Subsequently, we used the landslide and rainfall data to estimate the probability of various levels of landslide activity when the thresholds have been exceeded.

Analysis of hourly data from the 17 rain gages in Seattle's network indicated that the CT was exceeded about 4.4 percent 
of all time (average of all gages) between 1978 and 2003. Exceedance at individual gages ranged from 2.6 to 8.6 percent of the time (table 3 ). Threshold exceedance resulted from an average of 94 distinct events (62-154 distinct events at individual gages), of which an average of 85 (90 percent) were during the wet season. Only a fraction of these coincided with landslides near any individual gage. For example, a total of 105 separate events (continuous periods) exceeded the CT at gage 14 in west Seattle, and (assuming that there were few unreported landslides) only 40 percent (42/105) coincided with landslides that were within the domain of gage 14, which has more recorded historical landslides in its domain than any other gage (table 3). At the other gages, 4-41 percent of exceedance events are correlated with landslides. Considered on a day-by-day basis, the probability of landslides occurring on a day when the CT is exceeded ranges from about 1 to 10 percent depending on the gage (table 3 ). These low percentages correspond to a high proportion of false positives and indicate that additional factors may need to be considered in using the CT to forecast landslide activity in specific rain-gage domains.

We compiled statistics on CT exceedance for the three nearest gages to each of the 577 landslides (right column, table 1) to investigate the effect of spatial variability of rainfall on the frequency of CT exceedance for various levels of landslide activity (tables 4, 5, and 6). Joint exceedances at neighboring gages were not computed but must be high for events of three or more landslides, given that exceedance is greater than 90 percent at most gages. As a result of missing rainfall data spanning periods of months or years at four of the rain gages, exceedance statistics are not available for all landslides. The percent exceedance at the nearest gage, A, and the next-nearest gage, $B$, agrees within 1-2 percent (table 4). The percent exceedance between the nearest, A, and third-nearest gage, C, agrees within 3 percent. Although the high agreement between landslide events and exceedance is encouraging, it does not guarantee highly accurate predictions of landslides given threshold exceedance. The exceedance statistic is similar to the conditional probability of an exceedance given a landslide; operationally, we need an estimate of the conditional probability of a landslide given an exceedance.

The three nearest gages agree 86-92 percent of the time when the nearest gage is showing either exceedance or nonexceedance (table 5). The relatively high agreement between gages indicates that spatial variability, during the wet season, of rainfall with respect to the CT is sufficiently low that observations from gage $\mathrm{B}$ or $\mathrm{C}$ can probably be substituted for observations at gage $\mathrm{A}$.

Statistics in table 6 show exceedance with respect to landslides and days on which landslides occurred. Focusing first on landslides, a high percentage of landslides in our database have exceedance at one or two rain gages, 78-82 percent for the entire database of 577 landslides. Many landslides occur in the same 3-day period (446 of 577) or on the same day (393 of 577) and in both cases, a very large percentage (93-97 percent) has exceedance at one or two rain gages.
Focusing on days rather than landslides, statistics in table 6 indicate that, of the 172 days on which landslides in our database occurred, only 53 percent had CT exceedance. The CT failed to predict 47 percent of days on which landslides occurred; however, this is not an indicator of how reliable thresholds are as predictors. Chleborad (2003) found that a majority of landslides that occurred below the CT had a reported or identified human influence. Although about one-half the landslide days are predicted, the predicted days account for about 80 percent of the 577 landslides. Failure to predict greatly decreases if the landslide intensity increases. Of the 172 days, only 55 correspond to periods of three or more landslides in 3-day periods (three in 1 day, two in 1 day and one another day, or one each on 3 successive days). There is some overlap between the 3-day periods because 55 is not evenly divisible by 3 . However, a high percentage has exceedance at one ( 84 percent) or two (73 percent) gages. Finally, of the 172 days, only 20 correspond to days of three or more landslides in 1 day, and a similarly high percentage had exceedance at one ( 85 percent) or two (74 percent) rain gages. Table 6 shows that a large fraction of the landslides occurred on multiple-slide days and that multiple-slide days show a small failure to predict using the CT. What remains is to determine the prediction probability given the rainfall threshold criterion.

\section{Probability Estimates}

\section{Landslide Probability Given Cumulative Threshold Exceedance}

The exceedance statistics indicate that the CT has been exceeded for the vast majority of landslides that have occurred in groups of three or more, and it has often been exceeded on days when only one or two landslides have occurred. Therefore, the CT is a potentially useful indicator of conditions required for the occurrence of precipitation-induced landslides. However, rainfall thresholds are imperfect predictors of landslides, so probability estimates are needed to qualify forecasts of landslide occurrence that are based on the exceedance of a threshold. We estimated the probability of various levels of landslide occurrence when the CT has been exceeded as a guide for making decisions related to emergency preparedness (table 7). Probability of a specified number of landslides occurring on any day when the CT has been exceeded are based on analysis of historical records of landslide activity and rainfall at the gages in the Seattle rain-gage network.

\section{Procedure}

The large number of gages presents a number of possibilities for computing the probabilities, so we chose a procedure consistent with how we believe the CT would be used in forecasting landslide activity. Rainfall amounts and frequency of landslides vary spatially throughout the city, and landslides usually (but not always) occur near a gage where the CT has been exceeded, so exceedance of the $\mathrm{CT}$ at any of the 17 rain gages in the network indicates that landslides may occur somewhere 
Table 3. Cumulative 3-day and previous 15-day rainfall threshold (CT) exceedance at rain gages in the Seattle Rain Gage Network, 1978-2003.

\begin{tabular}{|c|c|c|c|c|c|c|c|c|c|}
\hline $\begin{array}{c}\text { Rain gage } \\
\text { number }\end{array}$ & Missing data & $\begin{array}{c}\text { Percentage } \\
\text { of time } \\
\text { exceeded }\end{array}$ & $\begin{array}{c}\text { Distinct } \\
\text { exceedance } \\
\text { events }\end{array}$ & $\begin{array}{c}\text { Average } \\
\text { duration of } \\
\text { exceedance } \\
\text { event (days) }\end{array}$ & $\begin{array}{l}\text { Number of } \\
\text { landslides } \\
\text { in domain }\end{array}$ & $\begin{array}{l}\text { Landslides } \\
\text { per } \\
\text { exceedance } \\
\text { event }\end{array}$ & $\begin{array}{l}\text { Number of } \\
\text { days on which } \\
\text { landslides } \\
\text { occurred in } \\
\text { domain (fig. 1) }\end{array}$ & $\begin{array}{c}\text { Days CT } \\
\text { exceeded } \\
\text { one hour or } \\
\text { more }\end{array}$ & $\begin{array}{l}\text { Conditional } \\
\text { probability } \\
\text { of landslides } \\
\text { occurring on a } \\
\text { day when the } \\
\text { threshold is } \\
\text { exceeded }\end{array}$ \\
\hline 1 & None & 3.47 & 71 & 4.6 & 13 & 0.183 & 10 & 390 & $0.026(10 / 390)$ \\
\hline 2 & None & 4.80 & 96 & 4.7 & 50 & 0.521 & 23 & 536 & $0.043(23 / 536)$ \\
\hline 3 & $\begin{array}{l}12 / 1 / 2003- \\
12 / 31 / 2003\end{array}$ & 3.34 & 79 & 4.0 & 20 & 0.253 & 11 & 383 & $0.029(11 / 383)$ \\
\hline 4 & None & 4.54 & 99 & 4.3 & 7 & 0.071 & 7 & 518 & $0.014(7 / 518)$ \\
\hline 5 & None & 4.02 & 97 & 3.9 & 32 & 0.330 & 16 & 461 & $0.035(16 / 461)$ \\
\hline 7 & $\begin{array}{l}1 / 1 / 1997- \\
1 / 31 / 1998\end{array}$ & 5.29 & 101 & 4.8 & 35 & 0.347 & 15 & 572 & $0.026(15 / 572)$ \\
\hline 8 & None & 4.37 & 118 & 3.5 & 22 & 0.186 & 16 & 521 & $0.031(16 / 521)$ \\
\hline 9 & None & 2.66 & 70 & 3.6 & 4 & 0.057 & 4 & 313 & $0.013(4 / 313)$ \\
\hline 10 & None & 5.02 & 105 & 4.5 & 19 & 0.181 & 12 & 567 & $0.021(12 / 567)$ \\
\hline 11 & None & 2.58 & 62 & 3.9 & 45 & 0.726 & 22 & 301 & $0.073(22 / 301)$ \\
\hline 12 & $\begin{array}{l}\text { 8/171998- } \\
12 / 31 / 2000\end{array}$ & 4.23 & 91 & 4.2 & 98 & 1.077 & 38 & 470 & $0.081(38 / 470)$ \\
\hline 14 & $\begin{array}{l}\text { 1/1/2001- } \\
12 / 31 / 2002\end{array}$ & 4.92 & 105 & 4.1 & 141 & 1.343 & 42 & 524 & $0.080(42 / 524)$ \\
\hline 15 & None & 4.44 & 92 & 4.6 & 19 & 0.207 & 11 & 501 & $0.022(11 / 501)$ \\
\hline 16 & $\begin{array}{r}10 / 16 / 2003- \\
10 / 22 / 2003\end{array}$ & 4.01 & 94 & 4.0 & 1 & 0.011 & 1 & 457 & $0.002(1 / 457)$ \\
\hline 17 & None & 8.56 & 154 & 5.3 & 9 & 0.058 & 7 & 948 & $0.007(7 / 948)$ \\
\hline 18 & None & 4.88 & 113 & 4.1 & 6 & 0.053 & 5 & 560 & $0.009(5 / 560)$ \\
\hline 20 & None & 4.42 & 95 & 4.4 & 56 & 0.589 & 29 & 496 & $0.058(29 / 496)$ \\
\hline Total & & & & & 577 & & & & \\
\hline $\begin{array}{l}\text { Year-round } \\
\text { average }\end{array}$ & & 4.44 & 94 & 4.3 & & & & & \\
\hline $\begin{array}{l}\text { Wet-season } \\
\text { average }\end{array}$ & & & 85 & & & & & & \\
\hline
\end{tabular}


Table 4. Exceedance statistics for cumulative 3-day and previous 15-day threshold (CT) at the three nearest rain gages to each landslide in the database.

[Gages A, B, and $\mathrm{C}$ are the three rain gages nearest to a landslide in the database, with the distance increasing in order from A to C. $P_{3}$ is the cumulative rainfall during the 3 days ( 72 hours) before the landslide, and $P_{15}$ is the cumulative rainfall for the 15 days before $P_{3}$.]

\begin{tabular}{|c|c|c|c|}
\hline Entire database (577 landslides) & Gage A & Gage B & Gage C \\
\hline Total landslides with estimates of $P_{3}$ and $P_{15}$ & 570 & 574 & 569 \\
\hline Total landslides for which estimates exceed threshold & 438 & 442 & 421 \\
\hline Percent exceedance & 77 & 77 & 74 \\
\hline \multicolumn{4}{|c|}{3 or more landslides in 3 days (446 landslides) } \\
\hline & Gage A & Gage B & Gage C \\
\hline Total landslides with estimates of $P_{3}$ and $P_{15}$ & 444 & 446 & 441 \\
\hline Total landslides for which rainfall exceeds threshold & 408 & 409 & 394 \\
\hline Percent exceedance & 92 & 92 & 89 \\
\hline \multicolumn{4}{|c|}{3 or more landslides in 1 day (393 landslides) } \\
\hline & Gage A & Gage B & Gage C \\
\hline Total landslides with estimates of $P_{3}$ and $P_{15}$ & 393 & 393 & 391 \\
\hline Total landslides for which rainfall exceeds threshold & 371 & 373 & 364 \\
\hline Percent exceedance & 94 & 95 & 93 \\
\hline \multicolumn{4}{|c|}{$\begin{array}{c}1 \text { or } 2 \text { landslides in } 1 \text { day (127 landslides, excluding those that are part of events of } 3 \text { or more landslides in } 3 \\
\text { days) }\end{array}$} \\
\hline & Gage A & Gage B & Gage C \\
\hline Total landslides with estimates of $P_{3}$ and $P_{15}$ & 124 & 126 & 126 \\
\hline Total landslides for which rainfall exceeds threshold & 29 & 31 & 26 \\
\hline Percent exceedance & 23 & 25 & 21 \\
\hline
\end{tabular}


Table 5. Rain-gage agreement with regard to exceedance or nonexceedance of cumulative 3-day and previous 15-day threshold (CT).

[Gages A, B, and $\mathrm{C}$ are the three rain gages nearest to a landslide in the database, with the distance increasing in order from $\mathrm{A}$ to $\mathrm{C}$. Good agreement-gages B and $\mathrm{C}$ in agreement with gage $\mathrm{A}$; fair agreement-gage $\mathrm{B}$ or $\mathrm{C}$ agrees with gage $\mathrm{A}$; poor agreement—neither gage $\mathrm{B}$ or gage $\mathrm{C}$ agrees with gage $\mathrm{A}$ ]

\begin{tabular}{ccccc}
\hline \multicolumn{1}{c}{ Database subset } & $\begin{array}{c}\text { Total number of landslides } \\
\text { with agreement data }\end{array}$ & \multicolumn{2}{c}{$\begin{array}{c}\text { Percentage agreement between three rain } \\
\text { gages nearest to each landslide }\end{array}$} \\
\cline { 3 - 5 } & 563 & Good & Fair & Poor \\
\hline $\begin{array}{c}\text { Entire database (577 } \\
\text { landslides) }\end{array}$ & 439 & 86 & 9 & 5 \\
$\begin{array}{c}3 \text { or more landslides in } 3 \\
\text { days (446 landslides } \\
\text { or more landslides in one } \\
\text { day (393 landslides) }\end{array}$ & 391 & 92 & 5 & 5 \\
\hline
\end{tabular}


Table 6. Lumped exceedance statistics for cumulative 3-day and previous 15-day threshold (CT) at the three nearest rain gages to each landslide in the database.

[--, information not available; $P_{3}$ is the cumulative rainfall during the 3 days (72 hours) before the landslide;

$P_{15}$ is the cumulative rainfall for the 15 days before $P_{3}$ ]

\begin{tabular}{|c|c|c|}
\hline \multirow{2}{*}{$\begin{array}{c}\text { Group } \\
\text { Entire database (577 landslides) }\end{array}$} & \multicolumn{2}{|c|}{$\begin{array}{l}\text { Minimum number of nearest gages exceeding } \\
\text { threshold }\end{array}$} \\
\hline & 1 of 3 & 2 of 3 \\
\hline Total landslides with estimates of $P_{3}$ and $P_{15}$ & 575 & 575 \\
\hline $\begin{array}{l}\text { Total landslides for which estimate exceeds } \\
\text { threshold }\end{array}$ & 474 & 449 \\
\hline Percent exceedance & 82 & 78 \\
\hline \multicolumn{3}{|l|}{ Three or more landslides in 3 days (446 landslides) } \\
\hline Total landslides with estimates of $P_{3}$ and $P_{15}$ & 444 & 443 \\
\hline $\begin{array}{l}\text { Total landslides for which estimate exceeds } \\
\text { threshold }\end{array}$ & 430 & 412 \\
\hline Percent exceedance & 97 & 93 \\
\hline \multicolumn{3}{|l|}{ Three or more landslides in 1 day (393 landslides) } \\
\hline Total landslides with estimates of $P_{3}$ and $P_{15}$ & 393 & 392 \\
\hline $\begin{array}{l}\text { Total landslides for which estimate exceeds } \\
\text { threshold }\end{array}$ & 383 & 374 \\
\hline Percent exceedance & 97 & 95 \\
\hline \multicolumn{3}{|l|}{ Days of one or more landslides (172 days) } \\
\hline $\begin{array}{l}\text { Total landslide days with estimates of } P_{3} \text { and } P_{15} \\
\text { Total days for which estimate exceeds threshold } \\
\text { Percent exceedance }\end{array}$ & $\begin{array}{r}172 \\
91 \\
53\end{array}$ & $\begin{array}{l}-- \\
-- \\
--\end{array}$ \\
\hline \multicolumn{3}{|l|}{ Days of three or more landslides in 3 days (55 days) } \\
\hline $\begin{array}{l}\text { Total landslide days with estimates of } P_{3} \text { and } P_{15} \\
\text { Total days for which estimate exceeds threshold } \\
\text { Percent exceedance }\end{array}$ & $\begin{array}{l}55 \\
46 \\
84\end{array}$ & $\begin{array}{l}52 \\
38 \\
73\end{array}$ \\
\hline \multicolumn{3}{|l|}{ Days of three or more landslides in 1 day ( 20 days) } \\
\hline Total landslide days with estimates of $P_{3}$ and $P_{15}$ & 20 & 19 \\
\hline Total days for which estimate exceeds threshold & 17 & 14 \\
\hline Percent exceedance & 85 & 74 \\
\hline
\end{tabular}


Table 7. Probability of landslide occurrence in Seattle relative to the 3-day and previous 15-day cumulative rainfall threshold (CT) based on number of unique days the threshold was exceeded at any rain gage from 1978-2003.

[Values based on records at the 17 rain gages in the Seattle rain-gage network. G denotes the average number of rain gages that were above the threshold on days when the specified number of landslides occurred; $I_{6}$ denotes the running 6-hour intensity. The CT was exceeded 1,182 days at one or more rain gages and 760 days at three or more gages throughout the city, out of 9,477 possible days. The CT was exceeded in combination with measurable rainfall $\left(I_{6}>0.001\right)$ on 974 days at one or more rain gages and 601 days at three or more rain gages. A total of 577 landslides occurred on 172 days. in/day, inches per day; N, number; \%, percentage; >, greater than]

\begin{tabular}{|c|c|c|c|c|c|c|c|c|}
\hline \multirow{3}{*}{$\begin{array}{l}\text { Landslides per } \\
\text { day } \\
\mathbf{N} \\
\end{array}$} & \multicolumn{8}{|c|}{ Minimum probability, $\mathrm{P}$ of $\mathrm{N}$ or more landslides on a day when conditions satisfied } \\
\hline & \multicolumn{3}{|c|}{$\begin{array}{l}\text { CT exceeded at one or } \\
\text { more rain gages }\end{array}$} & \multicolumn{3}{|c|}{$\begin{array}{c}\text { CT exceeded and } I_{6}>0.001 \\
\text { in/day at one or more rain } \\
\text { gages }\end{array}$} & \multicolumn{2}{|c|}{$\begin{array}{l}\text { CT not exceeded at any } \\
\text { rain gage }\end{array}$} \\
\hline & $P(\%)$ & Days & $\mathbf{G}$ & $\mathbf{P}(\%)$ & Days & G & $\mathbf{P}(\%)$ & Days \\
\hline 1 & 8.4 & $99 / 1,182$ & 5 & 9.3 & $91 / 974$ & 3 & 0.88 & $73 / 8,295$ \\
\hline 2 & 3.5 & $41 / 1,182$ & 8 & 4.0 & $39 / 974$ & 5 & 0.11 & $9 / 8,295$ \\
\hline 3 & 1.5 & $18 / 1,182$ & 8 & 1.9 & $18 / 974$ & 6 & 0.04 & $3 / 8,295$ \\
\hline 5 & 0.76 & $9 / 1,182$ & 14 & 0.92 & 9/974 & 10 & 0.00 & $0 / 8,295$ \\
\hline 50 & 0.25 & $3 / 1,182$ & 15 & 0.31 & $3 / 974$ & 15 & 0.00 & $0 / 8,295$ \\
\hline $\begin{array}{l}\text { Landslides per } \\
\text { day }\end{array}$ & $\begin{array}{l}\text { CT exc } \\
\text { or } n\end{array}$ & $\begin{array}{l}\text { led at any } \\
\text { e rain gag }\end{array}$ & & $\begin{array}{l}\text { CT ex } \\
\text { in/day }\end{array}$ & $\begin{array}{l}\text { eded and } \\
\text { any thre } \\
\text { rain gage }\end{array}$ & & & \\
\hline $\mathbf{N}$ & $\mathbf{P}(\%)$ & Days & $\mathbf{G}$ & $\mathbf{P}(\%)$ & Days & $\mathbf{G}$ & & \\
\hline 1 & 11 & $83 / 760$ & 5 & 12 & $75 / 601$ & 3 & & \\
\hline 2 & 5.1 & $39 / 760$ & 8 & 6.0 & $36 / 601$ & 5 & & \\
\hline 3 & 2.4 & $18 / 760$ & 8 & 3.0 & $18 / 601$ & 6 & & \\
\hline 5 & 1.2 & $9 / 760$ & 14 & 1.5 & $9 / 601$ & 10 & & \\
\hline 50 & 0.39 & $3 / 760$ & 15 & 0.50 & $3 / 601$ & 15 & & \\
\hline
\end{tabular}


in Seattle or its immediate vicinity. Consequently, we computed the probabilities based on the number of days on which one or more landslides occurred and rainfall exceeded the CT all or part of the day at one rain gage (table 7). To simplify calculations, we used days of CT exceedance at only one rain gage rather than trying to use data from three neighboring gages as in the previous section. We divided this number of days by the total number of days at which rainfall amounts exceeded the CT at any rain gage in the network so that no single rain gage was favored. Although data from any gage can be used in actual operation of a landslide forecasting system, it is best to rely on redundant gages whenever possible. Rainfall has occurred on most days that had significant numbers of landslides, so we also computed probability of landslide occurrence on days when more than 0.01 inch of rain fell (expressed as a non-zero 6-hour intensity). Finally, we computed the probability of landslides occurring on days when the CT had not been exceeded by dividing that number of days by the total number of days when the CT was not exceeded at any rain gage in the network.

\section{Probability Estimates for Cumulative Threshold Exceedance}

Table 7 shows our estimates of the probability of various numbers of landslides (left column) of occurring, given exceedance of the CT and nonexceedance of the CT (failure to predict). Of the 1,182 days when the CT was exceeded at one of the rain gages, one or more landslides occurred on 99 of those days, for a probability of 8.4 percent. Many of the days on which the CT has been exceeded were also rainy days; considering only rainy days when the CT was exceeded results in slightly higher probability of landslide occurrence. One or more landslides occurred on 91 of the 974 days on which the CT was exceeded and it rained, for a probability of 9.3 percent. In either case, exceedance of the CT indicates about a 10-percent chance of one or more landslides occurring, which is sufficient cause to alert officials and the public of the increased likelihood of landslides while the CT is exceeded.

Identifying days when a high probability of multiple landslides exists requires additional information. Looking down the columns of table 7 for days on which the CT was exceeded, the probability decreases as the number of landslides per day increases. Of the 99 days on which one or more landslides occurred and the CT was exceeded, only 3 of those days had 50 or more landslides. Large events (50 or more landslides) have a 0.25 percent $(3 / 1,182)$ chance of occurring on days when the CT has been exceeded and are extremely unlikely to occur when the CT has not been exceeded. Factors that help distinguish events that have large numbers of landslides from those that have small numbers of slides include the number of rain gages at which the CT has been exceeded, and rainfall intensity. The CT was usually exceeded at several rain gages on days when one or two landslides occurred and was exceeded at all working gages on days when large numbers of slides (50 or more) occurred, as shown in the columns marked $\mathrm{G}$ in table 7 .

\section{Failure to Predict for Cumulative Threshold}

Almost one-half (73 days) of the 172 days on which landslides occurred were on days when the CT was not exceeded; however, the frequency of these landslides is relatively low (table 7). One or more landslides occurred on 73 of the 8,295 days when the CT was not exceeded, for a probability of 0.88 percent. Days of multiple landslides when the CT was not exceeded were even fewer. A total of 86 of the 577 , or only 15 percent, landslides in the database (table 1) occurred on days when the CT was not exceeded. Thus, although the absolute number of days when the CT failed to predict landslides was fairly high, the rate of failure is low.

\section{Landslide Probability for Intensity-Duration Threshold and Antecedent Water Index Exceedance}

As noted previously, Godt (2004) and Godt and others (2006) developed a rainfall intensity-duration threshold (ID) and an antecedent water index (AWI) for Seattle in an effort to define a predictor of precipitation-induced, multiple-landslide events. Baum and others (2005) computed probability estimates for the ID and AWI in a manner similar to those presented in table 7 , except that the average number of periods when the ID was exceeded at all gages was used as the divisor, rather than the total days exceeded as in table 7 . Here, we have recomputed the probability using the total number of days the ID was exceeded at any rain gage in the network in order to facilitate comparison between the probabilities of landslide occurrence when either threshold (CT or ID) has been exceeded (table 8).

\section{Probability Estimates for Intensity-Duration Exceedance}

Table 8 is organized in a similar manner to table 7 and shows the estimated minimum probability of one or more landslides given exceedance of the ID and AWI at any rain gage in Seattle's network. The ID has a much lower rate of exceedance $(0.17$ percent) than the CT (4.4 percent). Consequently, the probability of landslide occurrence when the ID or the combined ID and AWI are exceeded is several times greater than when the CT is exceeded (tables 7 and 8). Landslides occurred on 36 of the 120 days when the ID was exceeded, for a probability of 30 percent, which is much higher than the probability of landslides given exceedance of the CT (table 7). Combined exceedance of the ID and the AWI results in slightly higher probability, 32 percent (28/87). As with the CT, probabilities are lower for multiple landslide days, but the probabilities are greater than for exceedance of the CT (tables 7 and 8). Note also that the number of rain gages where the ID was exceeded increases with the number of landslides. 
Table 8. Minimum probability of landslide occurrence in Seattle relative to the rainfall intensity-duration threshold (ID) and ID combined with the antecedent water index (AWI) based on number of days the threshold was exceeded at any rain gage from 1978-2003

[Values based on records at the 17 rain gages in the Seattle rain-gage network, G denotes the average number of rain gages that were above the threshold on days when the specified number of landslides occurred. The ID was exceeded on 120 days, at any gage throughout the city, out of 9,496 possible days. The ID and AWI, combined, were exceeded on 87 days. $\%$, percentage.]

\begin{tabular}{ccccccccr}
\hline Landslides per day & \multicolumn{5}{c}{ Probability, $\mathrm{P}$, of $\mathrm{N}$ or more landslides on a day when conditions satisfied } \\
\cline { 2 - 9 } & $\begin{array}{c}\text { ID exceeded at one or } \\
\text { more rain gages }\end{array}$ & \multicolumn{2}{c}{$\begin{array}{c}\text { ID and AWl exceeded at } \\
\text { one or more rain gages }\end{array}$} & $\begin{array}{c}\text { ID not exceeded at any } \\
\text { rain gage }\end{array}$ \\
\hline $\mathbf{N}$ & $\mathbf{P}(\%)$ & \multicolumn{1}{c}{ Days } & $\mathbf{G}$ & $\mathbf{P}(\%)$ & Days & $\mathbf{G}$ & $\mathbf{P ( \% )}$ & Days \\
\hline 1 & 30 & $36 / 120$ & 5 & 32 & $28 / 87$ & 6 & 1.5 & $136 / 9376$ \\
2 & 18 & $22 / 120$ & 9 & 23 & $20 / 87$ & 9 & 0.30 & $28 / 9376$ \\
3 & 10 & $12 / 120$ & 11 & 11 & $10 / 87$ & 11 & 0.10 & $9 / 9376$ \\
5 & 5.0 & $6 / 120$ & 12 & 6.9 & $6 / 87$ & 12 & 0.03 & $3 / 9376$ \\
50 & 1.7 & $2 / 120$ & 17 & 2.3 & $2 / 87$ & 17 & 0.01 & $1 / 9376$ \\
\hline
\end{tabular}

\section{Failure to Predict for Intensity-Duration Threshold and Antecedent Water Index}

Exceedance of the ID at any rain gage in the city predicted only 21 percent (36/172) of days when landslides occurred. These days account for 207 (36 percent) of the 577 landslides in the database (table 1). The higher probabilities of landslides given exceedance of the ID and AWI (table 8) compared to probabilities given exceedance of the CT (table 7) come at the cost of missing a larger proportion of days when one or more landslides occur and missing days when rapid snowmelt is a factor. The ID predicted only 36 days on which landslides occurred and did not predict 136 days. Many days when 1, 2, or 3 landslides have occurred had no rainfall or only low-intensity rainfall, so the ID predicts only a small proportion of days on which small numbers of landslides occur. The value of the ID is in predicting days when larger numbers of landslides are likely to occur. However, the ID also failed to predict 3 days when five or more landslides were reported: December 31, 1996 (10 landslides); January 1, 1997 (187 landslides); and November 15, 2001 (8 landslides). The landslides on November 15, 2001 occurred the day after a storm that exceeded the ID, and the other 2 days were associated with rapid melting of a heavy snowpack.

Neither the ID nor the 3-day/15-day CT specifically accounts for snowmelt, so additional factors must be considered when snow is on the ground (Chleborad, 2000). However, the daily contribution of snowmelt was estimated for the January 1, 1997, landslide event as part of the analysis to identify the CT (Chleborad, 2000), suggesting the feasibility of estimating equivalent precipitation amounts for applying the CT during snowmelt events. In operational use of the thresholds, snowmelt should be considered when more than 6 inches $(15 \mathrm{~cm})$ of snow is on the ground. Freeze-thaw is also suspected of initiating landslides (Tubbs, 1974); however, we have insufficient data to account for that factor.

\section{Function of Area of Exceedance in Improving Predictions}

As previously noted in tables 7 and 8, the number of landslides that occur on a given day tends to increase with the area over which the threshold has been exceeded (and probably how much the threshold has been exceeded). Table 9 indicates the probability of landslide occurrence when the ID and combined ID and AWI have been exceeded at any 3 gages and any 10 gages in the Seattle network. The probabilities for exceedance at any three or more gages (table 9) are about one-third higher than computed based on exceedance at a single rain gage (table 8). The probabilities of landslides given exceedance at 10 or more gages (table 9) are more than twice as high as probabilities computed on the basis of exceedance at a single gage (table 8). Comparing the upper and lower parts of table 9, the probability of landslides occurring is about 1.5 times higher on days when rainfall at 10 gages exceeds the ID than when rainfall at only 3 gages exceeds the ID. Regardless of the number of rain gages, the probability of landslide occurrence is somewhat greater on days when the ID and AWI are both exceeded.

Although not shown in table 9, the added criterion of exceedance at 10 rain gages slightly increased the number of days when landslides were not predicted and further reduces the number of landslides predicted. Exceedance of the ID at any 3 rain gages predicted about 33 percent of the landslides, and exceedance at any 10 gages predicted about 32 percent, compared with 36 percent for exceedance at any single rain gage. The criterion of exceedance at multiple rain gages increases the confidence in prediction of larger numbers of landslides, at the cost of missing most events that include only a few landslides. However, as a result of their low frequency, events with 50 or more landslides still have probabilities below 10 percent given exceedance of the ID or ID and AWI at 10 rain gages. 
Table 9. Probability of landslide occurrence in Seattle relative to the rainfall intensityduration threshold (ID) based on number of days the threshold was exceeded at 3 or more and 10 or more rain gages from 1978 to 2003

[Values based on records at the 17 rain gages in the Seattle rain-gage network. G denotes the average number of rain gages that were above the threshold on days when the specified number of landslides occurred. Over the entire network, the ID was exceeded on 64 days at 3 or more gages and 31 days at 10 or more gages. The combined ID and Antecedent Water Index (AWI) were exceeded on 48 days at 3 or more gages and 21 days at 10 or more gages. $\%$, percentage]

\begin{tabular}{|c|c|c|c|c|c|c|}
\hline \multirow{3}{*}{$\begin{array}{l}\text { Landslides per } \\
\text { day } \\
\mathbf{N}\end{array}$} & \multicolumn{6}{|c|}{$\begin{array}{c}\text { Minimum probability, } P \text {, of } N \text { or more landslides on a day } \\
\text { when conditions satisfied }\end{array}$} \\
\hline & \multicolumn{3}{|c|}{$\begin{array}{l}\text { ID exceeded at } 3 \text { or more } \\
\text { rain gages }\end{array}$} & \multicolumn{3}{|c|}{$\begin{array}{l}\text { ID and } \mathrm{AWI} \text { exceeded at } 3 \text { or } \\
\text { more rain gages }\end{array}$} \\
\hline & $\mathbf{P}(\%)$ & Days & $\mathbf{G}$ & $\mathbf{P}(\%)$ & Days & $\mathbf{G}$ \\
\hline 1 & 42 & $27 / 64$ & 5 & 48 & $23 / 48$ & 6 \\
\hline 2 & 28 & $18 / 64$ & 9 & 33 & $16 / 48$ & 9 \\
\hline 3 & 16 & $10 / 64$ & 11 & 19 & $9 / 48$ & 11 \\
\hline 5 & 9.4 & $6 / 64$ & 12 & 13 & $6 / 48$ & 12 \\
\hline 50 & 3.1 & $2 / 64$ & 17 & 4.2 & $2 / 48$ & 17 \\
\hline $\begin{array}{l}\text { Landslides per } \\
\text { day }\end{array}$ & \multicolumn{3}{|c|}{$\begin{array}{l}\text { ID exceeded at } 10 \text { or } \\
\text { more rain gages }\end{array}$} & \multicolumn{3}{|c|}{$\begin{array}{c}\mathrm{ID} \text { and } \mathrm{AWI} \text { exceeded at } 10 \text { or } \\
\text { more rain gages }\end{array}$} \\
\hline $\mathbf{N}$ & $\mathbf{P}(\%)$ & Days & $\mathbf{G}$ & $\mathbf{P}(\%)$ & Days & G \\
\hline 1 & 65 & $20 / 31$ & 5 & 71 & $15 / 21$ & 6 \\
\hline 2 & 48 & $15 / 31$ & 9 & 62 & $13 / 21$ & 9 \\
\hline 3 & 32 & $10 / 31$ & 11 & 43 & $9 / 21$ & 11 \\
\hline 5 & 19 & $6 / 31$ & 12 & 29 & $6 / 21$ & 12 \\
\hline 50 & 6.5 & $2 / 31$ & 17 & 9.5 & $2 / 21$ & 17 \\
\hline
\end{tabular}

\section{Other Factors Affecting Rainfall Measurements and Threshold Exceedance}

The issue of rainfall spatial variability has not been specifically addressed in this study, but variability over the distances involved can significantly affect estimates of cumulative precipitation or rainfall intensity and duration. Distances between landslides and corresponding rain gages have a mean value of $2.9 \mathrm{mi}(4.6 \mathrm{~km})$ and a standard deviation of $2.2 \mathrm{mi}(3.5 \mathrm{~km})$. Analysis of the frequency of rainfall threshold exceedance at the various gages (tables 3, 5, and 6) indicates that variability over some of the distances involved can significantly affect estimates of 3-day and prior 15-day precipitation. In addition, variability and possible errors associated with rain-gage design and placement have not been examined. For example, snowfall and wind conditions may significantly affect data accuracy. Landslide-prone areas in Seattle and vicinity have been mapped or identified in numerous studies and landslide recurrence intervals for the areas have been estimated (for example, Tubbs, 1974; Laprade and others, 2000; Baum and others, 1998; and Coe and others, 2004). Since variability with distance appears to be a significant factor, deployment of rain gages in known landslide-prone areas, or areas with a high frequency of landslide occurrence, could significantly reduce distances between future landslides and rain gages used to estimate amounts of antecedent precipitation and rainfall intensity, thus improving the rainfall estimates.

\section{Conclusions}

Despite uncertainties introduced by available rainfall data and historical records of landslide occurrence, our statistical analysis provides a basis for assessing the potential usefulness and reliability of the thresholds for emergency response planning. Due to underreporting of landslides, the computed probabilities are considered to be minimum values (tables 7, 8 and 9). Although many isolated landslides have occurred on days when the thresholds have not been exceeded, the CT was exceeded on more than 90 percent of 1-day and 3-day events with three or more landslides (table 4). Frequent exceedance of the CT (table 3 ) results in low to moderate probabilities of landslides occurring on any given day when the CT has been exceeded (table 7). Less frequent exceedance of the ID results in relatively higher probabilities of landslide occurrence, particularly as the number of rain gages at which the ID is exceeded increases (tables 8 and 9). Information about soil wetness helps to further reduce uncertainty about the likelihood of landslides (Baum and others, 2005). Although the computed probabilities indicate that considerable uncertainty exists even when the ID is exceeded at multiple rain gages and the AWI (or field instrumentation) indicates wet soil conditions, the probability of landslides under 
these conditions (table 9) is sufficiently high to warrant higher levels of warning than indicated by exceedance of the CT alone.

Experience in using the thresholds and other information will likely result in identification of new or additional criteria for increasing confidence in forecasts of landslide occurrence. Probability of landslide occurrence may change over time in the event of changing land use, local climate, or implementation of landslide-mitigation measures in hillside areas. Improved record keeping for future landslide events may some day allow for improved estimates of the probability of landslide occurrence on condition of rainfall threshold exceedance.

\section{References Cited}

Baum, R.L., Chleborad, A.F., Schuster, R.L., 1998, Landslides triggered by the winter 1996-97 storms in the Puget Lowland, Washington: U.S. Geological Survey Open-File Report 98-239, 16 p.

Baum, R.L., Godt, J.W., Harp, E.L., McKenna, J.W., and McMullen, S.R., 2005, Early warning of landslides for rail traffic between Seattle and Everett, Washington, USA, in Hungr, O., Fell, R., Couture, R., and Eberhardt, E., eds., Landslide risk management, Proceedings of the International Conference on Landslide Risk Management, Vancouver, Canada, May 30-June 3, 2005: New York, A.A. Balkema, p. 731-740.

Chleborad, A.F., 2000, A method for anticipating the occurrence of precipitation-induced landslides in Seattle, Washington: U.S. Geological Survey Open-File Report 2000-469, 29 p.

Chleborad, A.F., 2003, Preliminary evaluation of a precipitation threshold for anticipating the occurrence of landslides in the Seattle, Washington, area: U.S. Geological Survey Open-File Report 2003-463, 39 p.

Coe, J.A., Michael, J.A., Crovelli, R.A., Savage, W.Z., Laprade, W.T., and Nashem, W.D., 2004, Probabilistic assessment of precipitation-triggered landslides using historical records of landslide occurrence, Seattle, Washington. Environmental \& Engineering Geoscience, v. 10, no. 2, p. 103-122.

Cruden, D.M. and Varnes, D.J., 1996, Landslide types and processes, in Turner, A.K., and Schuster, R.L., LandslidesInvestigations and mitigation: Transportation Research Board Special Report 247, p. 36-75.
Gerstel, W.J., 1996, The upside of the landslides of February 1996 - Validating a stability analysis of the Capitol Campus Bluffs, Olympia, Washington: Washington Geology, v. 24, no. 3, p. 3-16.

Gerstel, W.J., Brunengo, M.J., Lingley, W.S., Logan, R.L., Shipman, H., and Walsh, T.J., 1997, Puget Sound bluffsThe where, why, and when of landslides following the holiday 1996/97 storms: Washington Geology, v. 25, p. 1731.

Godt, J.W., 2004, Observed and modeled conditions for shallow landsliding in the Seattle, Washington, area: Boulder, University of Colorado, Ph.D. dissertation, 151 p., 1 pl., 32 figs.

Godt, J.W., Baum, R.L, and Chleborad, A.F., 2006, Rainfall characteristics for shallow landsliding in Seattle, Washington, USA: Earth Surface Processes and Landforms, v. 31, p. 97110

Laprade, W.T., 1986, Unusual landslide processes, January 17 and 18, 1986, storm, Seattle, Washington, in Better living through engineering geology: Association of Engineering Geologists, 29th Annual Meeting, San Francisco, p. 55.

Laprade, W.T., Kirkland, T.E., Nashem, W.D., and Robertson, C.A., 2000, Seattle landslide study, Shannon and Wilson, Inc. Internal Report W-7992-01, 164 p. available at URL http:// www.seattle.gov/DPD/Landslide/Study/default.asp, accessed March 9, 2006.

Miller, D.J., 1991, Damage in King County from the storm of January 9, 1990: Washington Geology, v. 19, no. 11, p. 28-37.

Thorsen, G.W., 1989, Landslide provinces in Washington, in Engineering geology in Washington, Richard W. Galster, ed.: Washington Division of Geology and Earth Resources Bulletin 78, v. I, p. 71-89.

Tubbs, D.W., 1974, Landslides in Seattle: Washington Division of Geology and Earth Resources Information Circular 52, 15 p., 1 plate.

Varnes, D.J., 1978, Slope movement types and processes, in Schuster, R.L., and Krizek, R.J., eds., Landslides analysis and control: Transportation Research Board Special Report 176, p. 11-33. 
Table 1. 1978-2003 database of 577 Seattle landslides with known dates of occurrence. [Source is Seattle Landslide Database (Laprade and others, 2000), unless noted in parentheses after landslide identification number (leftmost column)]

\begin{tabular}{|c|c|c|c|}
\hline Landslide no. & Date of occurrence & Reference address & $\begin{array}{c}\text { Rain gages (nearest } \\
\text { first) }\end{array}$ \\
\hline 656 & $03 / 20 / 78$ & 2540 Dexter Ave. N. & $11,12,03$ \\
\hline 98 & $11 / 03 / 78$ & 714 S. Charles St. & $20,11,14$ \\
\hline 1444 & $12 / 05 / 78$ & $\begin{array}{l}\text { N. Northlake Way / } \\
\text { Wallin }\end{array}$ & $01,04,07$ \\
\hline 828 & $12 / 17 / 78$ & 1728 Alki Ave. SW & $14,11,15$ \\
\hline 743 & $12 / 15 / 79$ & 1027 California Ln. SW & $14,15,11$ \\
\hline 836 & $12 / 15 / 79$ & 1768 Alki Ave. SW & $14,15,11$ \\
\hline A52 (City files) & $12 / 17 / 79$ & $\begin{array}{l}\text { California Way SW at } \\
\text { California Pl. }\end{array}$ & $14,15,11$ \\
\hline A53 (City files) & $12 / 17 / 79$ & 1728 Alki Ave. SW & $14,15,11$ \\
\hline A54 (City files) & $12 / 17 / 79$ & $\begin{array}{l}\text { 21st Ave. SW and Croft } \\
\text { Pl. }\end{array}$ & $17,15,05$ \\
\hline A55 (City files) & $12 / 17 / 79$ & 3929 18th Ave. S. & $15,18,16$ \\
\hline A56 (City files) & $12 / 17 / 79$ & W. Raye St. & $12,08,11$ \\
\hline A57 (City files) & $12 / 17 / 79$ & Perkins Ln. (south end) & $12,08,11$ \\
\hline 1455 & $12 / 18 / 79$ & $\begin{array}{l}\text { Rainier Ave. S./S. Ryan } \\
\text { St. }\end{array}$ & $10,18,16$ \\
\hline A60 (City files) & $12 / 18 / 79$ & 7800 block of 41st Ave. & $18,16,10$ \\
\hline A94 (City files) & $12 / 27 / 79$ & $\begin{array}{l}\text { S. G. Galer (east of } 32 \mathrm{nd} \\
\text { Ave. W.) }\end{array}$ & $12,08,11$ \\
\hline 363 & $12 / 28 / 79$ & 1711 Perkins Ln. W. & $12,08,11$ \\
\hline 1429 & $12 / 28 / 79$ & $\begin{array}{l}\text { Perkins Ln. W./W. } \\
\text { Armour St. }\end{array}$ & $12,08,11$ \\
\hline 1057 & $01 / 12 / 80$ & 1925 Perkins Ln. W. & $12,08,11$ \\
\hline 269 & 02/08/80 & 5012 NE Laurelcrest Ln. & $03,02,20$ \\
\hline 829 & $02 / 28 / 80$ & 1728 Alki Ave. SW & $14,15,11$ \\
\hline 305 & 04/04/80 & 235 Lake Dell Ave. & $20,11,15$ \\
\hline 1013 & $04 / 28 / 80$ & $\begin{array}{l}\text { NE 98th St./20th Ave. } \\
\text { NE }\end{array}$ & $04,02,01$ \\
\hline 621 & $12 / 03 / 80$ & 9616 22nd Ct. NW & $20,11,15$ \\
\hline 270 & $12 / 31 / 80$ & 5012 NE Laurelcrest Ln. & $03,02,20$ \\
\hline 1315 & $03 / 13 / 81$ & 1200 S. Lane St. & $20,11,14$ \\
\hline 1233 & 03/17/81 & 1118 S. Dearborne St. & $20,11,14$ \\
\hline 189 & $01 / 18 / 82$ & 10508 Exeter Ave. NE & $02,04,03$ \\
\hline 1303 & $02 / 10 / 82$ & $\begin{array}{l}3804 \text { SW Massachusetts } \\
\text { Ave. }\end{array}$ & $14,15,11$ \\
\hline 212 & $02 / 19 / 82$ & 13720 40th Ave. NE & $02,01,04$ \\
\hline 663 & $02 / 20 / 82$ & 2558 Dexter Ave. N. & $11,20,03$ \\
\hline 195 & $03 / 12 / 82$ & 12328 Riviera Pl. NE & $02,04,01$ \\
\hline 837 & $12 / 03 / 82$ & 1768 Alki Ave. SW & $14,15,11$ \\
\hline 863 & $12 / 03 / 82$ & 2214 37th Ave. SW & $14,15,11$ \\
\hline 643 & $12 / 15 / 82$ & 1900 8th Ave. N. & $11,12,20$ \\
\hline 364 & $12 / 18 / 82$ & 1711 Perkins Ln. W. & $12,08,11$ \\
\hline 15 & $12 / 21 / 82$ & 1904 S. 19th Ave. & $15,20,11$ \\
\hline 590 & $12 / 21 / 82$ & 5631 Seaview Ave. NW & $08,12,07$ \\
\hline 776 & $01 / 04 / 83$ & 1333 Sunset Ave. SW & $14,15,11$ \\
\hline 800 & $01 / 04 / 83$ & $\begin{array}{l}1619 \text { Harbor Ave. SW } \\
18\end{array}$ & $14,15,11$ \\
\hline
\end{tabular}




\begin{tabular}{|c|c|c|c|}
\hline Landslide no. & Date of occurrence & Reference address & $\begin{array}{c}\text { Rain gages (nearest } \\
\text { first) }\end{array}$ \\
\hline 197 & $01 / 05 / 83$ & 12712 39th Ave. NE & $02,01,04$ \\
\hline 593 & 01/06/83 & 6703 36th Ave. NW & $08,12,09$ \\
\hline 1133 & $01 / 19 / 83$ & 168 Western Ave. W. & $11,20,14$ \\
\hline 213 & $02 / 18 / 83$ & 13720 40th Ave. NE & $02,01,04$ \\
\hline 450 & $02 / 18 / 83$ & 3033 W. Galer St. & $12,11,14$ \\
\hline 474 & $02 / 18 / 83$ & 3616 24th Ave. W. & $12,08,09$ \\
\hline 430 & $03 / 11 / 83$ & 2625 W. Galer St. & $12,11,14$ \\
\hline 1367 & $11 / 04 / 83$ & $\begin{array}{l}11145 \text { NW Carkeek } \\
\text { Park Rd. }\end{array}$ & $07,01,08$ \\
\hline 1026 & $11 / 11 / 83$ & 1300 Lakeside Ave. S. & $20,15,11$ \\
\hline 1420 & $11 / 24 / 83$ & $\begin{array}{l}\text { NE 115th St./Riviera } \\
\text { Pl. N. }\end{array}$ & $02,04,01$ \\
\hline 43 (OFR 00-469) & $12 / 09 / 83$ & 1717 Sturgus Ave. S. & $20,11,15$ \\
\hline 44 (OFR 00-469) & $12 / 10 / 83$ & 164 Lake Dell Ave. & $20,11,15$ \\
\hline 676 & $12 / 11 / 83$ & 714 W Galer St. & $11,12,14$ \\
\hline 45 (OFR 00-469) & $12 / 11 / 83$ & 1500 block of Aurora & $11,20,03$ \\
\hline 46 (OFR 00-469) & $12 / 12 / 83$ & $\begin{array}{l}\text { Ave. } \\
1700 \text { block of Sturgus } \\
\text { Ave. S. }\end{array}$ & $20,11,15$ \\
\hline 739 & $12 / 13 / 83$ & 8140 Detroit Ave. SW & $17,15,05$ \\
\hline 699 & $12 / 30 / 83$ & 9600 Rainier Ave. S. & $10,16,18$ \\
\hline 685 & $01 / 17 / 84$ & 11221 Crestwood Dr. S. & $12,08,11$ \\
\hline 13 & $02 / 24 / 84$ & 1717 Sturgus Ave. S. & $20,11,15$ \\
\hline 1014 & 03/07/84 & $\begin{array}{l}\text { NE 98th St./20th Ave. } \\
\text { NE }\end{array}$ & $04,02,01$ \\
\hline 990 & 04/10/84 & 6000 Atlas Pl. SW & $05,17,14$ \\
\hline 799 & 05/09/84 & 1617 Harbor Ave. SW & $14,15,11$ \\
\hline 418 & $05 / 15 / 84$ & 2535 Perkins Ln. W. & $12,08,11$ \\
\hline 1352 & 07/10/84 & 603 37th Ave. E. & $20,03,11$ \\
\hline 1438 & $08 / 02 / 84$ & $\begin{array}{l}\text { Golden Gardens Dr. NW } \\
\text { / View Ave }\end{array}$ & $08,07,12$ \\
\hline 101 & $12 / 08 / 84$ & 10047 47th Ave. SW & $05,17,14$ \\
\hline 438 & $12 / 28 / 84$ & 2809 46th Ave. W. & $12,08,11$ \\
\hline 415 & 05/04/85 & 2529 Perkins Ln. W. & $12,11,14$ \\
\hline 365 & $01 / 15 / 86$ & 1711 Perkins Ln. W. & $12,11,08$ \\
\hline 532 & $01 / 17 / 86$ & 10337 Bedford. Ct. NW & $07,08,01$ \\
\hline 1161 & $01 / 17 / 86$ & 4103 23rd Ave. SW & $14,15,17$ \\
\hline 47 & 01/18/86 & 1415 E. Interlaken Blvd. & $03,20,11$ \\
\hline 54 & 01/18/86 & 1500 Lakeview Blvd. E. & $20,11,03$ \\
\hline 80 & 01/18/86 & 2820 Eastlake Ave. E. & $20,11,03$ \\
\hline 99 & $01 / 18 / 86$ & 1000847 Ave. SW & $05,17,16$ \\
\hline 118 & $01 / 18 / 86$ & 1110430 Pl. SW & $05,17,16$ \\
\hline 125 & 01/18/86 & 503951 Ave. SW & $05,14,17$ \\
\hline 138 & 01/18/86 & 605350 Ave. SW & $05,14,17$ \\
\hline 150 & 01/18/86 & 653549 Ave. SW & $05,14,17$ \\
\hline 175 & 01/18/86 & 965348 Ave. SW & $05,17,16$ \\
\hline 226 & 01/18/86 & 2516 NE 97th St. & $04,02,03$ \\
\hline 259 & 01/18/86 & 4404 55th Ave. NE & $03,20,02$ \\
\hline 50 (OFR 00-469) & 01/18/86 & 1115 38th Ave. & $20,03,11$ \\
\hline 312 & $01 / 18 / 86$ & 31735 Ave. & $20,15,11$ \\
\hline
\end{tabular}




\begin{tabular}{|c|c|c|c|}
\hline Landslide no. & Date of occurrence & Reference address & $\begin{array}{c}\text { Rain gages (nearest } \\
\text { first) }\end{array}$ \\
\hline 316 & $01 / 18 / 86$ & 3216 E. Spruce St. & $20,11,03$ \\
\hline 330 & 01/18/86 & 425 Lakeside Ave. S. & $20,11,03$ \\
\hline 336 & $01 / 18 / 86$ & 530 36th Ave. E. & $20,11,03$ \\
\hline 345 & $01 / 18 / 86$ & 715 Randolph Pl. & $20,11,15$ \\
\hline 353 & $01 / 18 / 86$ & 1519 Magnolia Blvd. W. & $12,11,08$ \\
\hline 359 & $01 / 18 / 86$ & 1544 Magnolia Way W. & $12,11,08$ \\
\hline 377 & $01 / 18 / 86$ & 1800 Amherst Pl W & $12,11,08$ \\
\hline 420 & $01 / 18 / 86$ & 2557 Perkins Ln. W. & $12,11,08$ \\
\hline 429 & 01/18/86 & 262346 Ave. W. & $12,08,11$ \\
\hline 435 & $01 / 18 / 86$ & 2650 Perkins Ln. W. & $12,11,08$ \\
\hline 53 (OFR 00-469) & 01/18/86 & 3123 W. Harley St. & $08,12,09$ \\
\hline 471 & $01 / 18 / 86$ & 325323 Ave. W. & $12,11,08$ \\
\hline 496 & 01/18/86 & 112633 Ave. S. & $20,15,18$ \\
\hline 506 & $01 / 18 / 86$ & 3036 Cascadia Ave. S. & $15,16,18$ \\
\hline 517 & $01 / 18 / 86$ & 5317 S. Hudson St. & $15,16,18$ \\
\hline 591 & $01 / 18 / 86$ & 633 NW 120 St. & $07,01,04$ \\
\hline 592 & $01 / 18 / 86$ & 653237 Ave. NW & $08,12,07$ \\
\hline 47 (OFR 00-469) & $01 / 18 / 86$ & $\begin{array}{l}9252 \text { Greenwood Ave. } \\
\text { N. }\end{array}$ & $07,08,09$ \\
\hline 625 & $01 / 18 / 86$ & $1080 \mathrm{~W}$. Ewing & $08,12,09$ \\
\hline 649 & $01 / 18 / 86$ & 24488 Ave. N. & $11,20,12$ \\
\hline 650 & $01 / 18 / 86$ & 2501 Nob Hill Pl. N. & $11,20,12$ \\
\hline 686 & $01 / 18 / 86$ & 11221 Crestwood Dr. S. & $10,16,17$ \\
\hline 49 (OFR 00-469) & $01 / 18 / 86$ & 6131 S. Kepler St. & $10,18,16$ \\
\hline 695 & 01/18/86 & 6514 S. Norfolk St. & $10,16,18$ \\
\hline 714 & $01 / 18 / 86$ & 3617 19th Ave. SW & $14,15,16$ \\
\hline 744 & $01 / 18 / 86$ & $\begin{array}{l}1031 \text { California Lane } \\
\text { SW }\end{array}$ & $14,15,11$ \\
\hline 752 & $01 / 18 / 86$ & 1216 Alki Ave. SW & $14,15,11$ \\
\hline 48 (OFR 00-469) & $01 / 18 / 86$ & 1221 Harbor Ave. SW & $14,15,11$ \\
\hline 756 & $01 / 18 / 86$ & 1222 Alki Ave. & $14,15,11$ \\
\hline 771 & $01 / 18 / 86$ & 1325 Sunset Ave. SW & $14,15,11$ \\
\hline 791 & $01 / 18 / 86$ & 1436 Palm Ave. SW & $14,15,11$ \\
\hline 795 & $01 / 18 / 86$ & 1550 Alki Ave. SW & $14,15,11$ \\
\hline 798 & $01 / 18 / 86$ & 1617 Harbor Ave. SW & $14,15,11$ \\
\hline 52 (OFR 00-469) & $01 / 18 / 86$ & 1703 Harbor Ave. SW & $14,15,11$ \\
\hline 815 & $01 / 18 / 86$ & 1709 Harbor Ave. SW & $14,15,11$ \\
\hline 819 & $01 / 18 / 86$ & 1716 Victoria Ave. SW & $14,15,11$ \\
\hline 822 & $01 / 18 / 86$ & 1720 Palm Ave. SW & $14,15,11$ \\
\hline 823 & $01 / 18 / 86$ & 1720 Victoria Ave. SW & $14,15,11$ \\
\hline 51 (OFR 00-469) & $01 / 18 / 86$ & 1909 Sunset Ave. SW & $14,15,11$ \\
\hline 849 & $01 / 18 / 86$ & 1939 Walnut Ave. SW & $14,15,11$ \\
\hline 852 & $01 / 18 / 86$ & 210436 Ave. SW & $14,15,11$ \\
\hline 862 & $01 / 18 / 86$ & 2183 Sunset Ave. SW & $14,15,11$ \\
\hline 868 & 01/18/86 & 230437 Ave. SW & $14,15,11$ \\
\hline 870 & $01 / 18 / 86$ & 2304 Walnut Ave. SW & $14,15,11$ \\
\hline 874 & $01 / 18 / 86$ & 235147 Ave. SW & $14,15,11$ \\
\hline 875 & $01 / 18 / 86$ & 2366 Halleck Ave. SW & $14,15,11$ \\
\hline 891 & 01/18/86 & 321957 Ave. SW & $14,15,11$ \\
\hline 911 & $01 / 18 / 86$ & 4051 57th Ave. SW & $14,15,11$ \\
\hline
\end{tabular}




\begin{tabular}{|c|c|c|c|}
\hline Landslide no. & Date of occurrence & Reference address & $\begin{array}{c}\text { Rain gages (nearest } \\
\text { first) }\end{array}$ \\
\hline 920 & $01 / 18 / 86$ & 4406 SW Othello St. & $05,17,14$ \\
\hline 926 & 01/18/86 & 5068 Beach Dr. SW & $14,05,15$ \\
\hline 984 & $01 / 18 / 86$ & $\begin{array}{l}11640 \text { Seola Beach Dr. } \\
\text { SW }\end{array}$ & $05,17,10$ \\
\hline 54 (OFR 00-469) & $01 / 18 / 86$ & $\begin{array}{l}\text { 11th Ave. W./W. Galer } \\
\text { St. }\end{array}$ & $11,12,14$ \\
\hline 1139 & $01 / 18 / 86$ & 2005 14th Ave. W. & $11,12,14$ \\
\hline 1146 & $01 / 18 / 86$ & 2566 Nob Hill Pl. N. & $11,20,12$ \\
\hline 1221 & $01 / 18 / 86$ & 372258 Ave. SW & $14,15,05$ \\
\hline 1242 & 01/18/86 & 1660 E. Boston Terrace & $20,03,11$ \\
\hline 1305 & $01 / 18 / 86$ & 608 SW Austin Pl. & $17,16,05$ \\
\hline 1495 & 01/18/86 & 1800 Amherst Pl. W. & $12,11,08$ \\
\hline 709 & 01/19/86 & 9833 Rainier Ave. S. & $10,16,18$ \\
\hline 56 (OFR 00-469) & $01 / 19 / 86$ & $\begin{array}{l}2500 \text { block of NE } 97 \text { th } \\
\text { St. }\end{array}$ & $04,02,01$ \\
\hline 1301 & $01 / 19 / 86$ & $\begin{array}{l}2000 \text { block Bonair DR } \\
\text { SW }\end{array}$ & $14,15,11$ \\
\hline 1468 & $01 / 19 / 86$ & $\begin{array}{l}\text { SW Admiral Way / } \\
\text { Fairmount }\end{array}$ & $14,15,11$ \\
\hline 198 & $01 / 23 / 86$ & 1272323 Ave. NE & $01,02,04$ \\
\hline 801 & $01 / 24 / 86$ & 1619 Harbor Ave. SW & $14,15,11$ \\
\hline 1278 & $01 / 24 / 86$ & 383 NW 112 Pl. & $07,01,04$ \\
\hline 1390 & 02/07/86 & 2220 Bonair DR SW & $14,15,11$ \\
\hline 479 & 02/10/86 & 4506 W. Bertona St. & $12,08,09$ \\
\hline 599 & $02 / 10 / 86$ & 817 NW 118 St. & $07,01,08$ \\
\hline 562 & $02 / 13 / 86$ & 1303512 Ave. NW & $07,01,04$ \\
\hline 565 & $02 / 13 / 86$ & 1305512 Ave. NW & $07,01,04$ \\
\hline 597 & $02 / 13 / 86$ & 730934 Ave. NW & $08,12,07$ \\
\hline 1098 & $02 / 13 / 86$ & 10336 Bedford. Ct. NW & $07,08,09$ \\
\hline 1286 & $02 / 19 / 86$ & 1412 \& 142011 Ave. W. & $11,12,14$ \\
\hline 670 & $02 / 20 / 86$ & 362313 Ave. W. & $12,08,09$ \\
\hline 626 & $02 / 24 / 86$ & 11059 Ave. W. & $11,12,08$ \\
\hline 666 & $02 / 24 / 86$ & 29044 Ave. W. & $12,11,08$ \\
\hline 379 & $02 / 27 / 86$ & 1818 Amherst Pl. W. & $12,11,08$ \\
\hline 740 & $02 / 27 / 86$ & 925110 Ave. SW & $17,05,16$ \\
\hline 217 & $03 / 11 / 86$ & 1374040 Ave. NE & $01,02,04$ \\
\hline 533 & $03 / 17 / 86$ & 107349 Ave. NW & $07,08,09$ \\
\hline 618 & $03 / 19 / 86$ & 954531 Ave. NW & $07,08,09$ \\
\hline 804 & $03 / 21 / 86$ & 1671 Harbor Ave. SW & $14,15,11$ \\
\hline 812 & $03 / 21 / 86$ & 1703 Harbor Ave. SW & $14,15,11$ \\
\hline 818 & $03 / 21 / 86$ & 1715 Harbor Ave. SW & $14,15,11$ \\
\hline 857 & $11 / 23 / 86$ & 2142 Bonair Dr. SW & $14,15,11$ \\
\hline 1027 & $11 / 23 / 86$ & 1300 Lakeside Ave. S. & $20,15,18$ \\
\hline 805 & $02 / 02 / 87$ & 1671 Harbor Ave. SW & $14,15,11$ \\
\hline 813 & $02 / 02 / 87$ & 1703 Harbor Ave. SW & $14,15,11$ \\
\hline 816 & $02 / 02 / 87$ & 1709 Harbor Ave. SW & $14,15,11$ \\
\hline 941 & $02 / 11 / 87$ & 1045 S. main St. & $11,20,14$ \\
\hline 1000 & $03 / 03 / 87$ & 13658 41st Ave. NE & $02,01,04$ \\
\hline 806 & $03 / 12 / 87$ & 1671 Harbor Ave. SW & $14,15,11$ \\
\hline 807 & $03 / 26 / 87$ & 1671 Harbor Ave. SW & $14,15,11$ \\
\hline
\end{tabular}




\begin{tabular}{|c|c|c|c|}
\hline Landslide no. & Date of occurrence & Reference address & $\begin{array}{c}\text { Rain gages (nearest } \\
\text { first) }\end{array}$ \\
\hline 1439 & $03 / 30 / 87$ & $\begin{array}{l}\text { Golden Gardens Dr. NW } \\
\text { / View Ave. }\end{array}$ & IIIS) \\
\hline 921 & $11 / 29 / 88$ & $\begin{array}{l}4480 \text { Fauntleroy Way } \\
\text { SW }\end{array}$ & $14,15,05$ \\
\hline 260 & $03 / 12 / 89$ & 4560 55th Ave. NE & $03,02,20$ \\
\hline 1153 & $12 / 07 / 89$ & $\begin{array}{l}\text { Western Ave. W./1st } \\
\text { Ave. W. }\end{array}$ & $11,12,14$ \\
\hline 176 & 01/09/90 & 9803 49th Ave. SW & $05,17,14$ \\
\hline 302 & 01/09/90 & 222 Lake Dell Ave. & $20,11,15$ \\
\hline 703 & 01/10/90 & 9720 Rainier Ave. S. & $10,16,18$ \\
\hline 1089 & 03/05/90 & $\begin{array}{l}\text { Perkins Ln. W./W. Raye } \\
\text { St. }\end{array}$ & $12,08,09$ \\
\hline 7 & $12 / 31 / 90$ & 1111 S. Atlantic St. & $15,20,14$ \\
\hline 985 & $12 / 31 / 90$ & 3925 SW Arroyo Dr. & $05,17,16$ \\
\hline 352 & 02/06/91 & 1452 28th Ave. W. & $12,11,08$ \\
\hline 108 & 04/05/91 & 10447 47th Ave. SW & $05,17,16$ \\
\hline 170 & 04/05/91 & 9230 38th Ave. SW & $05,17,16$ \\
\hline 174 & 04/05/91 & $\begin{array}{l}9343 \text { Fauntleroy Way } \\
\text { SW }\end{array}$ & $05,17,16$ \\
\hline 59 (OFR 00-469) & 04/05/91 & 14250 40th Ave. NE & $01,04,02$ \\
\hline 60 (OFR 00-469) & 04/05/91 & 235 Lake Dell Ave. & $20,11,15$ \\
\hline 314 & 04/05/91 & 317 Lakeside Ave. S. & $20,15,11$ \\
\hline 1090 & 04/05/91 & $\begin{array}{l}\text { 28th Ave. S./S. Bayview } \\
\text { St. }\end{array}$ & $15,14,20$ \\
\hline 317 & 04/12/91 & 324 35th Ave. S. & $20,15,11$ \\
\hline 445 & 07/22/91 & 2845 Perkins Ln. W. & $12,08,11$ \\
\hline 109 & 01/30/92 & 10447 47th Ave. SW & $05,17,16$ \\
\hline 1074 & 09/24/92 & 2837 Perkins Ln. W. & $12,08,11$ \\
\hline 1411 & $09 / 29 / 94$ & $\begin{array}{l}\text { 20th Ave. N. / E. } \\
\text { crescent }\end{array}$ & $03,20,11$ \\
\hline 906 & $12 / 21 / 94$ & $\begin{array}{l}4014 \text { SW Massachusetts } \\
\text { St. }\end{array}$ & $14,15,11$ \\
\hline 298 & 02/19/95 & 201 Erie Ave. & $20,15,11$ \\
\hline 918 & 06/05/95 & 4206 Aikins Ave. SW & $14,15,11$ \\
\hline 1234 & $08 / 25 / 95$ & 1118 S. Dearborne St. & $20,15,11$ \\
\hline 855 & $11 / 11 / 95$ & 2140 Belvidere Ave. SW & $14,15,11$ \\
\hline 983 & $12 / 15 / 95$ & $\begin{array}{l}10700 \text { Seola Beach Dr. } \\
\text { SW }\end{array}$ & $05,17,16$ \\
\hline 1106 & $12 / 27 / 95$ & 3005 NW Esplanade & $07,08,09$ \\
\hline 104 & 02/08/96 & $\begin{array}{l}10233 \text { Marine View Dr. } \\
\text { SW }\end{array}$ & $05,17,16$ \\
\hline 181 & 02/08/96 & 470 N. 34th St. & $12,08,09$ \\
\hline 209 & 02/08/96 & 13538 42nd Ave. NE & $02,01,04$ \\
\hline 61 (OFR 00-469) & 02/08/96 & 4249 NE 89th St. & $02,04,03$ \\
\hline 494 & 02/08/96 & 4763 W. Roberts Way & $12,08,09$ \\
\hline 631 & 02/08/96 & 1125 9th Ave. W. & $11,12,14$ \\
\hline 768 & 02/08/96 & 1318 Palm Ave. SW & $14,15,11$ \\
\hline 982 & 02/08/96 & $\begin{array}{l}10611 \text { Marine View Dr. } \\
\text { SW }\end{array}$ & $05,17,16$ \\
\hline
\end{tabular}




\begin{tabular}{|c|c|c|c|}
\hline Landslide no. & Date of occurrence & Reference address & $\begin{array}{c}\text { Rain gages (nearest } \\
\text { first) }\end{array}$ \\
\hline 62 (OFR 00-469) & $02 / 09 / 96$ & $\begin{array}{l}9700 \text { block of Rainier } \\
\text { Ave. S. }\end{array}$ & $10,18,16$ \\
\hline 63 (OFR 00-469) & 02/09/96 & 5012 NE Laurelcrest Ln. & $03,02,20$ \\
\hline 788 & 02/09/96 & 1402 Palm Ave. SW & $14,15,11$ \\
\hline 1726 & 02/09/96 & 7540 57th Pl. NE & $02,04,03$ \\
\hline 227 & 02/10/96 & 2708 NE 98th St. & $04,02,01$ \\
\hline A41 (White Ctr. News) & 02/12/96 & $\begin{array}{l}1300 \text { block of California } \\
\text { Way SW }\end{array}$ & $14,11,15$ \\
\hline 477 & $02 / 16 / 96$ & 4433 W. Brygger Dr. & $08,12,09$ \\
\hline 366 & $02 / 26 / 96$ & 1729 Perkins Ln. W. & $12,08,11$ \\
\hline $\begin{array}{l}66 \text { (Harp and others, } \\
1996)\end{array}$ & 03/08/96 & 1734 Magnolia Blvd & $12,08,11$ \\
\hline $\begin{array}{l}62 \text { (Harp and others, } \\
1996)\end{array}$ & $04 / 23 / 96$ & $\begin{array}{l}2300 \text { block of Westlake } \\
\text { Ave }\end{array}$ & $11,09,12$ \\
\hline $\begin{array}{l}63 \text { (Harp and others, } \\
\text { 1996) }\end{array}$ & $04 / 23 / 96$ & $\begin{array}{l}\text { Perkins Ln and Raye St } \\
(0.4 \text { mi south })\end{array}$ & $12,08,11$ \\
\hline $\begin{array}{l}64 \text { (Harp and others, } \\
1996)\end{array}$ & $04 / 23 / 96$ & South end of Perkins Ln & $12,08,11$ \\
\hline 64 (OFR 00-469) & $12 / 29 / 96$ & $\begin{array}{l}13700 \text { block of } 40 \text { th } \\
\text { Ave. NE }\end{array}$ & $01,02,04$ \\
\hline 113 & $12 / 31 / 96$ & $\begin{array}{l}\text { 10607 Marine View Dr. } \\
\text { SW }\end{array}$ & $05,17,16$ \\
\hline 338 & $12 / 31 / 96$ & 602 36th Ave. E. & $20,03,11$ \\
\hline 66 (OFR 00-469) & $12 / 31 / 96$ & $\begin{array}{l}1300 \text { block of Alki Ave } \\
\text { SW }\end{array}$ & $14,15,11$ \\
\hline 67 (OFR 00-469) & $12 / 31 / 96$ & 2500 block of Dexter & $11,12,09$ \\
\hline 68 (OFR 00-469) & $12 / 31 / 96$ & $\begin{array}{l}\text { Ave. N. } \\
\text { Between } 1700 \text { \& } 2400 \\
\text { Perkins Ln }\end{array}$ & $12,08,11$ \\
\hline 69 (OFR 00-469) & $12 / 31 / 96$ & $\begin{array}{l}\text { Between } 1700 \& 2400 \\
\text { Perkins Ln }\end{array}$ & $12,08,11$ \\
\hline 70 (OFR 00-469) & $12 / 31 / 96$ & $\begin{array}{l}1900 \text { block of Perkins } \\
\text { Ln. W. }\end{array}$ & $12,08,11$ \\
\hline 71 (OFR 00-469) & $12 / 31 / 96$ & $\begin{array}{l}\text { Between } 1700 \& 2400 \\
\text { Perkins Ln }\end{array}$ & $12,08,11$ \\
\hline 664 & $12 / 31 / 96$ & 2562 5th Ave. N. & $11,12,09$ \\
\hline 1227 & $12 / 31 / 96$ & 5233 SW Jacobsen Rd. & $14,05,15$ \\
\hline 1 & 01/01/97 & 1002546 Ave. S. & $10,16,18$ \\
\hline 20 & 01/01/97 & 2501 13th Ave. S. & $15,20,14$ \\
\hline 30 & 01/01/97 & 3926 12th Ave. S. & $15,14,18$ \\
\hline 48 & 01/01/97 & 1415 E. Interlaken Blvd. & $20,03,11$ \\
\hline 55 & 01/01/97 & 1500 Lakeview Blvd. E. & $20,11,03$ \\
\hline 67 & 01/01/97 & 1651 10th Ave. E. & $20,11,03$ \\
\hline 68 & 01/01/97 & 1655 10th Ave. E. & $20,11,03$ \\
\hline 72 & 01/01/97 & 1824 Lakeview Blvd. E. & $20,11,03$ \\
\hline 74 & 01/01/97 & 1940 15th Ave. E. & $03,20,11$ \\
\hline 75 & 01/01/97 & 1655 E. Boston Terrace & $20,03,11$ \\
\hline 89 & 01/01/97 & 3136 Portage Bay Pl. E. & $03,20,11$ \\
\hline 90 & 01/01/97 & 3142 Fuhrman Ave. E. & $03,20,11$ \\
\hline 95 & 01/01/97 & 806 E. Blaine St. & $20,03,11$ \\
\hline
\end{tabular}




\begin{tabular}{|c|c|c|c|}
\hline Landslide no. & Date of occurrence & Reference address & $\begin{array}{c}\text { Rain gages (nearest } \\
\text { first) }\end{array}$ \\
\hline 107 & $01 / 01 / 97$ & 1044747 Ave. SW & $05,17,16$ \\
\hline 112 & 01/01/97 & $\begin{array}{l}\text { 10481 Maplewood Pl. } \\
\text { SW }\end{array}$ & $05,17,16$ \\
\hline 131 & 01/01/97 & 5933 Atlas Pl. SW & $05,14,15$ \\
\hline 137 & 01/01/97 & 6037 Beach Dr. SW & $14,05,15$ \\
\hline 139 & 01/01/97 & 612 SW Othello St. & $17,16,15$ \\
\hline 177 & 01/01/97 & 9803 49th Ave. SW & $05,17,14$ \\
\hline 180 & 01/01/97 & 4408 2nd Ave. NW & $09,08,12$ \\
\hline 183 & 01/01/97 & 2214 12th Ave. W. & $11,12,08$ \\
\hline 194 & 01/01/97 & 11740 Exeter Ave. NE & $02,04,01$ \\
\hline 201 & 01/01/97 & 13020 Riviera Pl. NE & $02,01,04$ \\
\hline 203 & 01/01/97 & 13200 Riviera Pl. NE & $02,01,04$ \\
\hline 204 & 01/01/97 & 13218 Riviera Pl. NE & $02,01,04$ \\
\hline 205 & 01/01/97 & 13226 42nd Ave. NE & $02,01,04$ \\
\hline 206 & 01/01/97 & 13240 42nd Ave. NE & $02,01,04$ \\
\hline 207 & 01/01/97 & 13502 42nd Ave. NE & $02,01,04$ \\
\hline 208 & 01/01/97 & 13530 Riviera Pl. NE & $02,01,04$ \\
\hline 210 & 01/01/97 & 13713 42nd Pl. NE & $02,01,04$ \\
\hline 215 & 01/01/97 & 1373039 Ave. NE & $02,01,04$ \\
\hline 224 & 01/01/97 & 14204 38th Ave. NE & $02,01,04$ \\
\hline 250 & 01/01/97 & 9416 20th Ave. NE & $04,02,01$ \\
\hline 263 & 01/01/97 & 4949 NE Laurelcrest Ln. & $03,02,20$ \\
\hline 292 & 01/01/97 & 1525 Grand Ave. & $20,03,11$ \\
\hline 295 & 01/01/97 & 1714 Evergreen $\mathrm{Pl}$. & $20,03,11$ \\
\hline 309 & 01/01/97 & 2573 Shoreland Dr. S. & $15,20,18$ \\
\hline 72 (OFR 00-469) & 01/01/97 & 1456 38th Ave. & $20,03,11$ \\
\hline 315 & 01/01/97 & 3213 E. Alder St. & $20,11,15$ \\
\hline 321 & 01/01/97 & 3320 Lakewood Ave. S. & $15,18,20$ \\
\hline 322 & 01/01/97 & 3346 Lakewood Ave. S. & $15,18,20$ \\
\hline 325 & 01/01/97 & 3740 E. John St. & $20,11,03$ \\
\hline 331 & 01/01/97 & 444 36th Ave. & $20,15,11$ \\
\hline 355 & 01/01/97 & 1519 Magnolia Blvd. W. & $12,11,08$ \\
\hline 367 & 01/01/97 & 1734 Magnolia Way W. & $12,11,08$ \\
\hline 372 & 01/01/97 & 1751 Perkins Ln. W. & $12,08,11$ \\
\hline 376 & 01/01/97 & 1767 Perkins Ln. W. & $12,08,11$ \\
\hline 380 & 01/01/97 & 1903 Clise Pl. W. & $12,08,11$ \\
\hline 381 & 01/01/97 & 1931 Perkins Ln. W. & $12,08,11$ \\
\hline 386 & 01/01/97 & 1949 Perkins Ln. W. & $12,08,11$ \\
\hline 388 & 01/01/97 & 1959 Perkins Ln. W. & $12,08,11$ \\
\hline 389 & 01/01/97 & 1967 Perkins Ln. W. & $12,08,11$ \\
\hline 392 & 01/01/97 & 2315 Perkins Ln. W. & $12,08,11$ \\
\hline 394 & 01/01/97 & 2336 Magnolia Blvd. W. & $12,08,11$ \\
\hline 396 & 01/01/97 & 2338 Perkins Ln. W. & $12,08,11$ \\
\hline 397 & 01/01/97 & 2339 Perkins Ln. W. & $12,08,11$ \\
\hline 398 & 01/01/97 & 2347 Perkins Ln. W. & $12,08,11$ \\
\hline 404 & 01/01/97 & 2364 Perkins Ln. W. & $12,08,11$ \\
\hline 407 & 01/01/97 & 2451 Perkins Ln. W. & $12,08,11$ \\
\hline 409 & 01/01/97 & 2479 Perkins Ln. W. & $12,08,11$ \\
\hline 73 (OFR 00-469) & 01/01/97 & 2529 Perkins Ln. W. & $12,08,11$ \\
\hline 74 (OFR 00-469) & 01/01/97 & 2543 Perkins Ln. W. & $12,08,11$ \\
\hline 421 & 01/01/97 & $\begin{array}{l}2557 \text { Perkins Ln. W. } \\
24\end{array}$ & $12,08,11$ \\
\hline
\end{tabular}




\begin{tabular}{|c|c|c|c|}
\hline Landslide no. & Date of occurrence & Reference address & $\begin{array}{l}\text { Rain gages (nearest } \\
\text { first) }\end{array}$ \\
\hline 428 & $01 / 01 / 97$ & 2600 Perkins Ln. W. & $12,08,11$ \\
\hline 436 & 01/01/97 & 2801 46th Ave. W. & $12,08,11$ \\
\hline 439 & 01/01/97 & 2809 46th Ave. W. & $12,08,11$ \\
\hline 442 & 01/01/97 & 2845 Patten Pl. W. & $12,08,11$ \\
\hline 446 & 01/01/97 & 3005 Perkins Ln. W. & $12,08,11$ \\
\hline 452 & 01/01/97 & 3045 Perkins Ln. W. & $12,08,11$ \\
\hline 454 & 01/01/97 & 3047 W. Galer St. & $12,08,11$ \\
\hline 461 & 01/01/97 & 3211 Perkins Ln. W. & $12,08,11$ \\
\hline 463 & 01/01/97 & 3212 23rd Ave. W. & $12,08,11$ \\
\hline 77 (OFR 00-469) & 01/01/97 & 3223 Perkins Ln. W. & $12,08,11$ \\
\hline 480 & 01/01/97 & 4511 W. Dravus St. & $12,08,11$ \\
\hline 513 & 01/01/97 & 4203 S. Mead St. & $18,16,15$ \\
\hline 520 & 01/01/97 & 1022 NW Elford Dr. & $07,01,04$ \\
\hline 540 & 01/01/97 & $\begin{array}{l}1206 \text { NW Culbertson } \\
\text { Dr. }\end{array}$ & $01,07,04$ \\
\hline 543 & 01/01/97 & $\begin{array}{l}1212 \text { NW Culbertson } \\
\text { Dr. }\end{array}$ & $01,07,04$ \\
\hline 555 & 01/01/97 & 12235 12th Ave. NW & $07,01,04$ \\
\hline 561 & 01/01/97 & 1290 NW Elford Dr. & $07,01,04$ \\
\hline 578 & 01/01/97 & $\begin{array}{l}1954 \text { NW Blue Ridge } \\
\text { Dr. }\end{array}$ & $07,08,09$ \\
\hline 595 & 01/01/97 & 672134 Ave. NW & $08,07,09$ \\
\hline 601 & 01/01/97 & 9025 26th Ave. NW & $07,08,09$ \\
\hline 606 & 01/01/97 & 2611 NW 92nd St. & $07,08,09$ \\
\hline 607 & 01/01/97 & 920924 Ave. NW & $07,08,09$ \\
\hline 610 & 01/01/97 & 9215 24th Ave. NW & $07,08,09$ \\
\hline 611 & 01/01/97 & 9215 View Ave. NW & $07,08,09$ \\
\hline 627 & 01/01/97 & 1105 9th Ave. W. & $08,12,07$ \\
\hline 635 & 01/01/97 & 1400 11th Ave. W. & $11,12,08$ \\
\hline 642 & 01/01/97 & 1610 12th Ave. W. & $11,12,08$ \\
\hline 646 & 01/01/97 & 2219 11th Ave. W. & $11,12,08$ \\
\hline 648 & 01/01/97 & 2400 Westlake Ave. N. & $11,12,09$ \\
\hline 658 & 01/01/97 & 2540 Westlake Ave. N. & $11,12,09$ \\
\hline 662 & 01/01/97 & 2558 Dexter Ave. N. & $11,12,09$ \\
\hline 673 & 01/01/97 & 445 Smith St. & $11,12,09$ \\
\hline 674 & 01/01/97 & 474 Wheeler St. & $11,12,09$ \\
\hline 680 & 01/01/97 & 908 W. Highland Dr. & $11,12,08$ \\
\hline 700 & 01/01/97 & 9600 Rainier Ave. S. & $10,16,18$ \\
\hline 713 & 01/01/97 & 3021 SW Bradford St. & $14,15,05$ \\
\hline 726 & 01/01/97 & 4832 35th Ave. SW & $14,15,05$ \\
\hline 732 & 01/01/97 & 5617 30th Ave. SW & $14,15,05$ \\
\hline 745 & 01/01/97 & 1104 Alki Ave. SW & $14,15,11$ \\
\hline 747 & 01/01/97 & 1122 Alki Ave. SW & $14,15,11$ \\
\hline 748 & 01/01/97 & 1140 Alki Ave. SW & $14,15,11$ \\
\hline 749 & 01/01/97 & 1140 Alki Ave. SW & $14,15,11$ \\
\hline 761 & 01/01/97 & 1315 Sunset Ave. SW & $14,15,11$ \\
\hline 777 & 01/01/97 & 1333 Sunset Ave. SW & $14,15,11$ \\
\hline 781 & 01/01/97 & 1356 Alki Ave. SW & $14,15,11$ \\
\hline 785 & 01/01/97 & 1400 Alki Ave. SW & $14,15,11$ \\
\hline 792 & 01/01/97 & 1502 Palm Ave. SW & $14,15,11$ \\
\hline
\end{tabular}




\begin{tabular}{|c|c|c|c|}
\hline Landslide no. & Date of occurrence & Reference address & $\begin{array}{c}\text { Rain gages (nearest } \\
\text { first) }\end{array}$ \\
\hline 796 & $01 / 01 / 97$ & 1564 Alki Ave. SW & $14,15,11$ \\
\hline 803 & 01/01/97 & 1659 Harbor Ave. SW & $14,15,11$ \\
\hline 808 & 01/01/97 & 1700 Victoria Ave. SW & $14,15,11$ \\
\hline 825 & 01/01/97 & 1726 Alki Ave. SW & $14,15,11$ \\
\hline 830 & 01/01/97 & 1732 Alki Ave. SW & $14,15,11$ \\
\hline 831 & 01/01/97 & 1736 Alki Ave. SW & $14,15,11$ \\
\hline 832 & 01/01/97 & 1752 Alki Ave. SW & $14,15,11$ \\
\hline 835 & 01/01/97 & 1768 Alki Ave. SW & $14,15,11$ \\
\hline 839 & 01/01/97 & 1772 Alki Ave. SW & $14,15,11$ \\
\hline 841 & 01/01/97 & 1910 Bonair Dr. SW & $14,15,11$ \\
\hline 842 & 01/01/97 & 1911 36th Ave. SW & $14,15,11$ \\
\hline 845 & 01/01/97 & 1929 Sunset Ave. SW & $14,15,11$ \\
\hline 846 & 01/01/97 & 1929 Bonair Dr. SW & $14,15,11$ \\
\hline 878 & 01/01/97 & 2419 54th Pl. SW & $14,15,11$ \\
\hline 880 & 01/01/97 & 2424 Hobart Ave. SW & $14,15,11$ \\
\hline 897 & 01/01/97 & 3507 SW Hanford St. & $14,15,11$ \\
\hline 915 & 01/01/97 & 4057 23rd Ave. SW & $14,15,05$ \\
\hline 930 & 01/01/97 & 5332 SW Lander St. & $14,15,11$ \\
\hline 931 & 01/01/97 & 5352 SW Lander St. & $14,15,11$ \\
\hline 933 & 01/01/97 & 5510 SW Lander St. & $14,15,11$ \\
\hline 936 & 01/01/97 & 5625 SW Teig Pl. & $14,15,11$ \\
\hline 938 & 01/01/97 & 2375 Hughes Ave. SW & $14,15,11$ \\
\hline 954 & 01/01/97 & 1517 Lakeview Blvd. E. & $20,11,03$ \\
\hline 958 & 01/01/97 & 1620 E. Boston & $03,20,11$ \\
\hline 969 & 01/01/97 & 2921 Franklin Ave. E. & $03,09,11$ \\
\hline 973 & 01/01/97 & E. Lynn St./13th Ave. E. & $03,09,11$ \\
\hline 998 & 01/01/97 & 1302039 Ave. NE & $02,01,04$ \\
\hline 1001 & 01/01/97 & 13730 42nd Ave. NE & $02,01,04$ \\
\hline 1010 & 01/01/97 & $\begin{array}{l}\text { NE 142nd St./41st Ave. } \\
\text { NE }\end{array}$ & $02,01,04$ \\
\hline 1049 & $01 / 01 / 97$ & 1700 Perkins Ln. W. & $12,08,11$ \\
\hline 1071 & 01/01/97 & 2600 W Marina Pl. & $12,11,14$ \\
\hline 1075 & 01/01/97 & 2900 Perkins Ln. W. & $12,08,11$ \\
\hline 1078 & 01/01/97 & 3061 W. Galer St. & $12,08,11$ \\
\hline 1082 & 01/01/97 & $\begin{array}{l}\text { 32nd Ave. W./W. Galer } \\
\text { St. }\end{array}$ & $12,08,11$ \\
\hline 1100 & 01/01/97 & 1250 NW Elford Dr. & $07,01,04$ \\
\hline 1107 & 01/01/97 & 3251 NW Esplanade & 07, 08, 09 \\
\hline 1120 & 01/01/97 & 7000 Seaview Ave. NW & $08,12,07$ \\
\hline 1126 & 01/01/97 & $\begin{array}{l}\text { NW 61st St./36th Ave. } \\
\text { NW }\end{array}$ & $08,12,07$ \\
\hline 1142 & 01/01/97 & 2100 Westlake Ave. N. & $11,20,03$ \\
\hline 1147 & 01/01/97 & 2600 Westlake Ave. N. & $11,20,03$ \\
\hline 1174 & 01/01/97 & 9800 Myers Way S. & $17,16,05$ \\
\hline 1178 & 01/01/97 & $\begin{array}{l}1019 \text { California Ave. } \\
\text { SW }\end{array}$ & $14,15,11$ \\
\hline 1181 & 01/01/97 & 1164 Alki Ave. SW & $14,15,11$ \\
\hline 1186 & 01/01/97 & 1206 Alki Ave. SW & $14,15,11$ \\
\hline 1191 & 01/01/97 & 1323 Sunset Ave. SW & $14,15,11$ \\
\hline 1192 & 01/01/97 & 1366 Alki Ave. SW & $14,15,11$ \\
\hline
\end{tabular}




\begin{tabular}{|c|c|c|c|}
\hline Landslide no. & Date of occurrence & Reference address & $\begin{array}{c}\text { Rain gages (nearest } \\
\text { first) }\end{array}$ \\
\hline 1208 & $01 / 01 / 97$ & 1737 Bonair Dr. SW & $14,15,11$ \\
\hline 1209 & 01/01/97 & $\begin{array}{l}1911 \text { Fairmount Ave. } \\
\text { SW }\end{array}$ & $14,15,11$ \\
\hline 1214 & 01/01/97 & 3000 SW Manning St. & $14,15,11$ \\
\hline 1230 & 01/01/97 & Ferry Ave. SW/ & $14,15,11$ \\
\hline 1251 & 01/01/97 & $\begin{array}{l}\text { Edgewood Ave. } \\
6333 \text { NE Windemere } \\
\text { Rd. }\end{array}$ & $03,02,04$ \\
\hline 1271 & 01/01/97 & $\begin{array}{l}1207 \text { NW Culbertson } \\
\text { Dr. }\end{array}$ & $01,07,04$ \\
\hline 1280 & 01/01/97 & 9231 View Ave. NW & $07,08,09$ \\
\hline 1293 & 01/01/97 & 6505 S. Norfork & $10,16,17$ \\
\hline 1302 & 01/01/97 & 2328 SW Walnut & $14,15,11$ \\
\hline 1335 & 01/01/97 & 11526 Riviera Pl. NE & $02,04,01$ \\
\hline 1336 & 01/01/97 & 13242 Riviera Pl. NE & $02,01,04$ \\
\hline 1381 & 01/01/97 & $\begin{array}{l}6020 \text { west Marginal } \\
\text { Way S. }\end{array}$ & $17,16,05$ \\
\hline 1385 & 01/01/97 & 1007 Alki Ave. SW & $14,15,11$ \\
\hline 1387 & 01/01/97 & 1023 Alki Ave. SW & $14,15,11$ \\
\hline 1388 & 01/01/97 & 1521 Bonair Dr. SW & $14,15,11$ \\
\hline 1394 & 01/01/97 & 3500 Schmitz Ave. SW & $14,15,11$ \\
\hline 1396 & 01/01/97 & 4019 Aikens Ave. SW & $14,15,11$ \\
\hline 1398 & 01/01/97 & 4206 Aikens Ave. SW & $14,15,11$ \\
\hline 1412 & 01/01/97 & $\begin{array}{l}\text { E. Boston Terrace/15th } \\
\text { Ave. }\end{array}$ & $03,20,11$ \\
\hline 1423 & 01/01/97 & $\begin{array}{l}\text { NE 95th St./Sand Point } \\
\text { Way }\end{array}$ & $02,04,03$ \\
\hline 1443 & 01/01/97 & $\begin{array}{l}\text { W. 92nd St./25th Ave. } \\
\text { NW }\end{array}$ & $07,08,09$ \\
\hline 1456 & 01/01/97 & $\begin{array}{l}\text { 23rd Ave. SW/SW } \\
\text { Dakota St. }\end{array}$ & $15,14,11$ \\
\hline 1459 & 01/01/97 & $\begin{array}{l}\text { W. Marginal Way SW/ } \\
\text { Highland }\end{array}$ & $16,17,05$ \\
\hline 1462 & 01/01/97 & $\begin{array}{l}\text { California Way SW/ } \\
\text { Ferry }\end{array}$ & $14,15,11$ \\
\hline 1474 & 01/01/97 & Southwest Lincoln. Park & $05,17,14$ \\
\hline 1475 & 01/01/97 & Southwest Lincoln. Park & $05,17,14$ \\
\hline 1485 & 01/01/97 & 1800 Amherst Pl. W. & $12,11,08$ \\
\hline 1487 & 01/01/97 & $\begin{array}{l}\text { 40th Ave. W./W. } \\
\text { Commodore Way }\end{array}$ & $08,12,09$ \\
\hline 1497 & 01/01/97 & $\begin{array}{l}1504 \text { NW Woodbine } \\
\text { Way }\end{array}$ & $07,01,04$ \\
\hline 1498 & 01/01/97 & MP-10.2 & $07,01,04$ \\
\hline 1531 & 01/01/97 & 1711 Perkins Ln W & $12,08,11$ \\
\hline 214 & 01/02/97 & 13720 40th Ave. NE & $02,01,04$ \\
\hline 356 & 01/02/97 & 1524 Magnolia Way W. & $12,11,08$ \\
\hline 81 (OFR 00-469) & 01/03/97 & $\begin{array}{l}1500 \text { block Lakeview } \\
\text { Blvd }\end{array}$ & $20,03,11$ \\
\hline 1718 & 01/03/97 & $\begin{array}{l}14285 \text { Sherwood Rd. } \\
\text { NW }\end{array}$ & $01,07,04$ \\
\hline
\end{tabular}




\begin{tabular}{|c|c|c|c|}
\hline Landslide no. & Date of occurrence & Reference address & $\begin{array}{c}\text { Rain gages (nearest } \\
\text { first) }\end{array}$ \\
\hline 82 (OFR 00-469) & $01 / 04 / 97$ & $\begin{array}{l}\text { north end of California } \\
\text { Way SW }\end{array}$ & $14,15,11$ \\
\hline 902 & 01/19/97 & 3632 SW Othello St. & $05,17,14$ \\
\hline 410 & 02/13/97 & 2479 Perkins Ln. W. & $12,08,11$ \\
\hline 83 (OFR 00-469) & 03/18/97 & $\begin{array}{l}1500 \text { block of Alki Ave. } \\
\text { SW }\end{array}$ & $14,15,11$ \\
\hline 85 (OFR 00-469) & 03/18/97 & $\begin{array}{l}1900 \text { block of } 17 \text { th Ave. } \\
\text { S. }\end{array}$ & $20,15,18$ \\
\hline 1516 & 03/18/97 & 4803 18th Ave. SW & $15,16,14$ \\
\hline 18 & 03/19/97 & 1923 17th Ave. S. & $15,20,14$ \\
\hline 22 & 03/19/97 & 2917 12th Ave. S. & $15,20,14$ \\
\hline 39 & 03/19/97 & 882639 Ave. S. & $10,16,18$ \\
\hline 41 & 03/19/97 & 883839 Ave. S. & $10,16,18$ \\
\hline 86 (OFR 00-469) & 03/19/97 & $\begin{array}{l}\text { Aurora Ave. (east side } \\
\text { Queen Anne) }\end{array}$ & $11,12,03$ \\
\hline 87 (OFR 00-469) & 03/19/97 & $\begin{array}{l}7700 \text { block of } 45 \text { th Ave. } \\
\text { SW }\end{array}$ & $05,17,14$ \\
\hline 88 (OFR 00-469) & 03/19/97 & $\begin{array}{l}\text { 17th Ave. and S. Plum } \\
\text { St. }\end{array}$ & $15,14,20$ \\
\hline 89 (OFR 00-469) & 03/19/97 & $\begin{array}{l}2300 \text { block of Westlake } \\
\text { Ave. N. }\end{array}$ & $11,12,03$ \\
\hline 90 (OFR 00-469) & 03/19/97 & $\begin{array}{l}3000 \text { block of NE } \\
\text { Perkins Way }\end{array}$ & $12,08,11$ \\
\hline 91 (OFR 00-469) & 03/19/97 & $\begin{array}{l}1700 \text { block of Magnolia } \\
\text { Way W. }\end{array}$ & $12,11,08$ \\
\hline 43 & 03/19/97 & 9363 Beacon Ave. S. & $10,16,18$ \\
\hline 71 & 03/19/97 & 1820 Lakeview Blvd. & $20,11,03$ \\
\hline 87 & 03/19/97 & 3136 Fuhrman Ave. E. & $03,20,11$ \\
\hline 132 & 03/19/97 & 5940 Beach Dr. SW & $14,05,15$ \\
\hline 160 & 03/19/97 & 7717 44th Ave. SW & $05,17,14$ \\
\hline 188 & 03/19/97 & 8615 Inverness Dr. NE & $02,04,03$ \\
\hline 304 & 03/19/97 & 222 Lake Dell Ave. & $20,11,15$ \\
\hline 332 & 03/19/97 & 45739 Ave. E. & $20,03,11$ \\
\hline 344 & 03/19/97 & 646 32nd Ave. E. & $20,03,11$ \\
\hline 382 & 03/19/97 & 1945 Perkins Ln. W. & $12,08,11$ \\
\hline 393 & 03/19/97 & 2332 Perkins Ln. W. & $12,08,11$ \\
\hline 441 & 03/19/97 & 2831 Perkins Ln. W. & $12,08,11$ \\
\hline 451 & 03/19/97 & 3033 W. Galer St. & $12,08,11$ \\
\hline 458 & 03/19/97 & 3121 W. Galer St. & $12,08,11$ \\
\hline 470 & 03/19/97 & 3233 Magnolia Blvd. W. & $12,08,11$ \\
\hline 515 & 03/19/97 & 4508 S. Ferdinand St. & $18,16,15$ \\
\hline 516 & 03/19/97 & 4722 53rd Ave. SW & $14,05,15$ \\
\hline 534 & 03/19/97 & 10745 11th Ave. NW & $07,01,04$ \\
\hline 553 & 03/19/97 & $\begin{array}{l}1222 \text { NW Culbertson } \\
\text { Dr. }\end{array}$ & $01,07,04$ \\
\hline 557 & 03/19/97 & 1248 NW 126th St. & $07,01,04$ \\
\hline 613 & 03/19/97 & 9221 View Ave. NW & $08,12,07$ \\
\hline 636 & 03/19/97 & 1403 W. Howe St. & $11,12,08$ \\
\hline 637 & 03/19/97 & 1408 Van Buren Ave. W. & $11,12,08$ \\
\hline 641 & 03/19/97 & 1606 12th Ave. W. & $11,12,08$ \\
\hline
\end{tabular}




\begin{tabular}{|c|c|c|c|}
\hline Landslide no. & Date of occurrence & Reference address & $\begin{array}{c}\text { Rain gages (nearest } \\
\text { first) }\end{array}$ \\
\hline 647 & $03 / 19 / 97$ & 2220 5th Ave. N. & $11,12,08$ \\
\hline 678 & 03/19/97 & $\begin{array}{l}\text { 801-805 W. Nickerson } \\
\text { St. }\end{array}$ & $09,12,08$ \\
\hline 772 & $03 / 19 / 97$ & 1330 Alki Ave. SW & $14,15,11$ \\
\hline 783 & 03/19/97 & 1370 Alki Ave. SW & $14,15,11$ \\
\hline 817 & 03/19/97 & 1714 Palm Ave. SW & $14,15,11$ \\
\hline 851 & 03/19/97 & 1940 Bonair Dr. SW & $14,15,11$ \\
\hline 889 & 03/19/97 & 3142 Alki Ave. SW & $14,15,11$ \\
\hline 899 & 03/19/97 & 360461 Ave. SW & $14,15,11$ \\
\hline 925 & 03/19/97 & 5027 51st Ave. SW & $14,05,15$ \\
\hline 955 & 03/19/97 & 1531 E. Olin Pl. & $20,11,03$ \\
\hline 1115 & 03/19/97 & MP-7.7 & $07,08,09$ \\
\hline 1177 & 03/19/97 & 1007 Harbor Ave. SW & $14,15,11$ \\
\hline 1218 & 03/19/97 & 3604 36th Ave. SW & $14,15,11$ \\
\hline 1219 & 03/19/97 & 3714 19th Ave. SW & $14,15,11$ \\
\hline 1290 & $03 / 19 / 97$ & 946 Elliot Ave. W. & $11,12,14$ \\
\hline 1484 & 03/19/97 & 1544 Magnolia Blvd W. & $12,08,11$ \\
\hline 182 & 03/20/97 & 5401 baker Ave. NW & $09,08,12$ \\
\hline 1288 & 03/20/97 & 908 Elliot Ave. W. & $11,12,14$ \\
\hline 1289 & 03/23/97 & 934 Elliot Ave. W. & $11,12,14$ \\
\hline A44 (White Ctr. News) & 04/02/97 & $\begin{array}{l}\text { California Way } \\
\text { SW/1500 block Harbor } \\
\text { Ave. }\end{array}$ & $14,11,15$ \\
\hline 1494 & $10 / 30 / 97$ & 809 W Nickerson St. & $09,12,11$ \\
\hline 1489 & $11 / 26 / 97$ & 6101 Ravenna Ave NE & $03,04,02$ \\
\hline 473 & $12 / 31 / 97$ & 3434 Perkins Ln. W. & $12,08,11$ \\
\hline 1391 & $12 / 31 / 97$ & 2634 Hobart Ave. SW & $14,15,11$ \\
\hline 1493 & $01 / 14 / 98$ & $\begin{array}{l}600 \text { Block NW Carkeek } \\
\text { Pk Rd. }\end{array}$ & $07,01,04$ \\
\hline 1490 & $01 / 25 / 98$ & $\begin{array}{l}1300 \text { Block California } \\
\text { Way }\end{array}$ & $14,15,11$ \\
\hline 1491 & $01 / 25 / 98$ & 3100 SW Admiral Way & $14,15,11$ \\
\hline 1488 & $02 / 13 / 98$ & 2466 55th Ave. SW & $14,15,11$ \\
\hline $\begin{array}{l}\text { A45 (Seattle Times } \\
\text { online) }\end{array}$ & $11 / 25 / 98$ & I-5 near S. 178th St. & $10,17,16$ \\
\hline 1703 & 01/13/99 & 940 NW Culbertson Dr. & $01,07,04$ \\
\hline 1510 & $01 / 28 / 99$ & 1626 20th E & $20,03,11$ \\
\hline 1514 & 01/30/99 & 1300 W Galer St & $12,08,11$ \\
\hline 1691 & 02/20/99 & 8427 1st Ave. S & $17,15,14$ \\
\hline 1695 & $02 / 24 / 99$ & 3013 SW Admiral Way & $14,15,11$ \\
\hline 1696 & $02 / 24 / 99$ & 3901 SW Barton St. & $05,17,14$ \\
\hline 76 (OFR 00-469) & $02 / 25 / 99$ & 7000 Seaview Ave NW & $08,07,09$ \\
\hline 1522 & $02 / 25 / 99$ & SW Ferry Ave & $14,15,11$ \\
\hline 1702 & $02 / 25 / 99$ & 2610 20th Ave. W & $12,11,08$ \\
\hline 1700 & 02/26/99 & 900 Dexter Ave. N & $11,20,03$ \\
\hline 1701 & $02 / 26 / 99$ & 13749 41st Ave. NE & $02,04,01$ \\
\hline 1609 & $04 / 12 / 99$ & $\begin{array}{l}9556 \text { Lake Shore Blvd. } \\
\text { NE }\end{array}$ & $02,04,01$ \\
\hline 1608 & $04 / 12 / 99$ & 13551 42nd Ave. NE & $02,04,01$ \\
\hline 1614 & $10 / 27 / 99$ & 4403 48th Ave. SW & $14,05,15$ \\
\hline
\end{tabular}




\begin{tabular}{|c|c|c|c|}
\hline Landslide no. & Date of occurrence & Reference address & $\begin{array}{c}\text { Rain gages (nearest } \\
\text { first) }\end{array}$ \\
\hline 1616 & $11 / 10 / 99$ & 7184 Sylvan Way SW & $05,15,14$ \\
\hline 1604 & $12 / 02 / 99$ & 120 32nd Ave. & $20,11,15$ \\
\hline 1615 & $12 / 16 / 99$ & 2128 SW Holden St. & $05,17,16$ \\
\hline 1618 & 01/12/00 & 3025 W Howe St. & $12,11,08$ \\
\hline 1619 & $02 / 15 / 00$ & 4049 35th Ave. W & $08,12,09$ \\
\hline 1622 & 03/16/00 & 2328 Delmar DR E & $03,20,11$ \\
\hline 1606 & $03 / 28 / 00$ & 1705 Aurora Ave. N & $11,20,03$ \\
\hline 1624 & $08 / 21 / 00$ & 2012 NE 52nd St. & $03,02,04$ \\
\hline 1682 & 02/28/01 & 2315 Arch Ave. SW & $14,15,11$ \\
\hline 1 (OFR 03-463) & $11 / 02 / 01$ & 1651 10th Ave. E & $20,11,03$ \\
\hline 3 (OFR 03-463) & $11 / 14 / 01$ & 3047 W Galer St. & $12,11,08$ \\
\hline 6 (OFR 03-463) & $11 / 14 / 01$ & $\begin{array}{l}\text { Opposite } 12720 \text { Riviera } \\
\text { Pl. NE }\end{array}$ & $02,04,01$ \\
\hline 11 (OFR 03-463) & $11 / 15 / 01$ & $\begin{array}{l}\text { Opposite } 13038 \text { Riviera } \\
\text { Pl. NE }\end{array}$ & $02,04,01$ \\
\hline 12 (OFR 03-463) & $11 / 15 / 01$ & $\begin{array}{l}\text { Opposite } 11728 \text { Riviera } \\
\text { Pl. NE }\end{array}$ & $02,04,01$ \\
\hline 10 (OFR 03-463) & $11 / 15 / 01$ & $\begin{array}{l}\text { Opposite } 12582 \text { Riviera } \\
\text { Pl. NE }\end{array}$ & $02,04,01$ \\
\hline 13 (OFR 03-463) & $11 / 15 / 01$ & $\begin{array}{l}\text { Opposite } 12328 \text { Riviera } \\
\text { Pl. NE }\end{array}$ & $02,04,01$ \\
\hline 14 (OFR 03-463) & $11 / 15 / 01$ & $\begin{array}{l}\text { Opposite } 13200 \text { Riviera } \\
\text { Pl. NE. }\end{array}$ & $02,01,04$ \\
\hline 15 (OFR 03-463) & $11 / 15 / 01$ & Discovery Park & $08,12,09$ \\
\hline 1660 & $11 / 15 / 01$ & 11532 Lakeside Ave. NE & $02,04,01$ \\
\hline 1661 & $11 / 15 / 01$ & 12064 Lakeside Pl. NE & $02,04,01$ \\
\hline 1636 & $11 / 19 / 01$ & 412 36th Ave. & $20,11,15$ \\
\hline 20 (OFR 03-463) & $11 / 21 / 01$ & 12321 25th Ave. NE & $02,04,01$ \\
\hline 18 (OFR 03-463) & $11 / 21 / 01$ & 3624 NW 65th Ct. & $08,07,12$ \\
\hline 1662 & $11 / 21 / 01$ & 1956 4th Ave. W & $11,12,09$ \\
\hline 22 (OFR 03-463) & $11 / 23 / 01$ & $\begin{array}{l}\text { Opposite } 12344 \text { Riviera } \\
\text { Pl NE. }\end{array}$ & $02,04,01$ \\
\hline 23 (OFR 03-463) & $11 / 25 / 01$ & $\begin{array}{l}\text { Opposite } 12344 \text { Riviera } \\
\text { Pl NE. }\end{array}$ & $02,04,01$ \\
\hline 25 (OFR 03-463) & $11 / 26 / 01$ & 4275 NE 125th St. & $02,04,01$ \\
\hline 1664 & $12 / 03 / 01$ & 3012 S Dawson St. & $18,15,16$ \\
\hline 1665 & $12 / 05 / 01$ & 4215 36th Ave. W & $08,12,09$ \\
\hline 1666 & $12 / 13 / 01$ & 2704 36th Ave. SW & $14,15,11$ \\
\hline 1667 & $12 / 13 / 01$ & 10223 Waters Ave. S & $10,16,18$ \\
\hline 35 (OFR 03-463) & $12 / 16 / 01$ & $\begin{array}{l}2100 \text { block of } 18 \text { th Ave. } \\
\text { S. }\end{array}$ & $15,20,18$ \\
\hline 40 (OFR 03-463) & $12 / 16 / 01$ & 1110 W Garfield St. & $11,12,08$ \\
\hline 34 (OFR 03-463) & $12 / 16 / 01$ & $\begin{array}{l}\text { Lake Washington Blvd } \\
\text { and 46th Ave. }\end{array}$ & $18,16,10$ \\
\hline 1639 & $12 / 16 / 01$ & $\begin{array}{l}3807 \text { Lake Washington } \\
\text { Blvd. S }\end{array}$ & $18,16,15$ \\
\hline 32 (OFR 03-463) & $12 / 16 / 01$ & 9057 Renton Ave. S & $10,16,17$ \\
\hline 33 (OFR 03-463) & $12 / 16 / 01$ & 9743 Rainier Ave. S & $10,16,17$ \\
\hline 37 (OFR 03-463) & $12 / 16 / 01$ & $\begin{array}{l}10300 \text { block of Bedford } \\
\text { Ct. NW }\end{array}$ & $07,08,09$ \\
\hline
\end{tabular}




\begin{tabular}{|c|c|c|c|}
\hline Landslide no. & Date of occurrence & Reference address & $\begin{array}{c}\text { Rain gages (nearest } \\
\text { first) }\end{array}$ \\
\hline 36 (OFR 03-463) & $12 / 16 / 01$ & 2546 Gilman Dr. W & $12,11,08$ \\
\hline 39 (OFR 03-463) & $12 / 16 / 01$ & $\begin{array}{l}1200 \text { block of NW } \\
\text { Elford Dr. }\end{array}$ & $01,07,04$ \\
\hline 1673 & $12 / 16 / 01$ & 1008 NW Elford Dr. & $01,07,04$ \\
\hline 1720 & $12 / 18 / 01$ & 4275 NE 125th St. & $02,04,01$ \\
\hline 1721 & $12 / 18 / 01$ & 12724 42nd Ave. NE & $02,04,01$ \\
\hline 1668 & $12 / 18 / 01$ & 5314 S Hudson St. & $15,16,14$ \\
\hline 1669 & $12 / 19 / 01$ & 4007 S Dakota St. & $15,16,14$ \\
\hline 1670 & $12 / 19 / 01$ & 1467 Van Buren Ave. W & $11,12,14$ \\
\hline 1671 & $12 / 20 / 01$ & 10339 Bedford Ct. NW & $07,08,01$ \\
\hline 1672 & $12 / 20 / 01$ & 10337 Bedford Ct. NW & $07,08,01$ \\
\hline 45 (OFR 03-463) & 01/08/02 & $\begin{array}{l}1600 \text { block of Harbor } \\
\text { Ave. }\end{array}$ & $14,15,11$ \\
\hline 1676 & 01/08/02 & 1545 Sunset Ave. SW & $14,15,11$ \\
\hline 1685 & $01 / 10 / 02$ & 3113 W Harley St. & $08,12,09$ \\
\hline 1645 & 01/15/02 & 9218 3rd Ave. SW & $17,16,05$ \\
\hline 1677 & $01 / 19 / 02$ & 2030 Bonair DR SW & $14,15,11$ \\
\hline 1679 & $01 / 25 / 02$ & 4517 W Dravus St. & $12,08,09$ \\
\hline 1680 & $01 / 25 / 02$ & 6712 8th Ave. NE & $04,09,03$ \\
\hline 1646 & $01 / 31 / 02$ & 11939 Lakeside Pl. NE & $02,01,04$ \\
\hline 1648 & 05/09/02 & 1111 38th Ave. & $20,03,11$ \\
\hline 1649 & $05 / 20 / 02$ & 1106 23rd Ave. E & $20,03,11$ \\
\hline 1 (OFR 03-463) & $11 / 23 / 02$ & $\begin{array}{l}\text { Schmitz Park and } \\
\text { Admiral Way }\end{array}$ & $14,15,11$ \\
\hline 7 (OFR 03-463) & $03 / 22 / 03$ & $\begin{array}{l}2900 \text { block of NW 96th } \\
\text { St. }\end{array}$ & $07,08,09$ \\
\hline $\begin{array}{l}1 \text { (R. McIntosh, City of } \\
\text { Seattle) }\end{array}$ & $10 / 20 / 03$ & $\begin{array}{l}10100 \text { block of Rainier } \\
\text { Ave. S }\end{array}$ & $10,18,16$ \\
\hline $\begin{array}{l}2 \text { (M. Orth, City of } \\
\text { Seattle) }\end{array}$ & $10 / 20 / 03$ & 12300 Riviera Pl NE & $02,04,03$ \\
\hline $\begin{array}{l}3 \text { (M. Orth, City of } \\
\text { Seattle) }\end{array}$ & $10 / 20 / 03$ & 12700 Riviera Pl NE & $02,04,03$ \\
\hline $\begin{array}{l}4 \text { (M. Orth, City of } \\
\text { Seattle) }\end{array}$ & $10 / 20 / 03$ & 11900 Riviera Pl NE & $02,04,03$ \\
\hline $\begin{array}{l}5 \text { (M. Orth, City of } \\
\text { Seattle) }\end{array}$ & $10 / 21 / 03$ & $\begin{array}{l}\text { Near west end of W. } \\
\text { Armory Way }\end{array}$ & $12,11,09$ \\
\hline $\begin{array}{l}6 \text { (C. Paston, City of } \\
\text { Seattle) }\end{array}$ & $11 / 19 / 03$ & $\begin{array}{l}7400 \text { block of 34th Ave } \\
\text { NW }\end{array}$ & $08,07,09$ \\
\hline
\end{tabular}

